\title{
Impacts of the Source and Amount of Crude Protein on the Intestinal Supply of Nitrogen Fractions and Performance of Dairy Cows*
}

\author{
I. R. Ipharraguerre and J. H. Clark \\ Department of Animal Sciences, University of Illinois, Urbana 61801
}

\begin{abstract}
The objective of this article was to review and summarize the significance of the amount and source of dietary crude protein supplements on the supply of nitrogen fractions passing to the small intestine and the performance of lactating dairy cows. A meta-analysis was used to evaluate 2 data sets, one for nitrogen flow to the small intestine and one for performance of cows. The response of dairy cows to rumen-undegradable protein supplements is variable. A portion of this variable response from research trials is explained by the source of crude protein in the control diet, the proportion and source of rumen-undegradable protein in the experimental diet, the effect of rumen-undegradable protein on microbial protein outflow from the rumen, the degradability and amino acid content of the rumen-undegradable protein, and the crude protein percentage of the diet. Compared with soybean meal, the mean milk production responses to feeding rumen-undegradable protein supplements ranged from -2.5 to $+2.75 \%$. Because of the large variation and small magnitude of response when rumen-undegradable protein supplements are fed compared with soybean meal, efficiency of nitrogen utilization and the cost to benefit ratio for these crude protein supplements may determine the source and amount of crude protein to feed to dairy cows in the future.
\end{abstract}

(Key words: dairy cow performance, meta-analysis, nitrogen flow to small intestine, rumen-undegradable protein)

Abbreviation key: EAA = essential amino acids, NANMN = nonammonia, nonmicrobial N, RUP mix = a mixture of animal, marine, and/or plant protein, SBM = solvent-extracted soybean meal.

\section{INTRODUCTION}

At the onset of a new century, continued increases in cow productivity and growing concerns about the

Received August 11, 2004.

Accepted November 2, 2004.

Corresponding author: J. H. Clark; e-mail: jhclark@uiuc.edu.

*Presented at the ADSA/ASAS/PSA Joint Annual Meeting, July 2004, St. Louis, MO. environment and safety of food for human and animal consumption in combination with the shrinking profits of dairy producers have renewed a challenge faced by scientists for $100 \mathrm{yr}$. That challenge is that nutritionists must establish the minimal amount of protein required by high-producing dairy cows to achieve optimal, but not necessarily maximal, milk production. In addition, it is important to identify sources of supplemental protein that will accomplish this goal with maximal nutritional efficiency while minimizing environmental concerns and economical costs.

The objectives of this article were to review and summarize the effects of the amount and source of dietary $\mathrm{CP}$ supplements on the supply of $\mathrm{N}$ fractions passing to the small intestine and the performance of lactating dairy cows. Data from the literature were quantitatively summarized using meta-analyses. This summary will focus on providing estimates of the magnitude and significance of documented alterations in the supply of $\mathrm{N}$ fractions to the small intestine and performance of dairy cows in response to manipulations of the amount and source of dietary CP.

\section{Statistical Analysis of Data from Literature}

To summarize the available data from the literature, a meta-analytic technique (Curtis and Wang, 1998; Hedges et al., 1999) was used to evaluate 2 data sets: one for $\mathrm{N}$ flow from the rumen to the small intestine and one for performance of lactating dairy cows. Treatment comparisons from the compiled studies were expressed as the natural log of the response ratio, which was defined as the ratio between the responses to supplemental RUP sources in the experimental diets and supplemental CP sources in the control diets. For each data set, results from compiled studies were tested for homogeneity to determine if the data from different studies could be pooled. This was accomplished by grouping treatment comparisons into categories described by CP source in the control diet, supplemental RUP source in the experimental diet, percentage of $\mathrm{CP}$ supplied as RUP, and total N intake. Subsequently, groups of comparisons were tested for homogeneity between and within groups. 
Table 1. Descriptive statistics of the $\mathrm{N}$ flow data set. ${ }^{1}$

\begin{tabular}{|c|c|c|c|c|c|c|}
\hline Item & $n^{2}$ & Minimum & Maximum & Median & Mean & SD \\
\hline DIM, d & 210 & 16 & 250 & 107 & 111 & 64.6 \\
\hline DMI, kg/d & 224 & 10.8 & 26.8 & 19.6 & 19.5 & 3.4 \\
\hline Forage, $\%$ of diet DM & 224 & 5.7 & 100 & 50.0 & 49.7 & 12.4 \\
\hline $\mathrm{CP}, \%$ of diet $\mathrm{DM}$ & 222 & 11.3 & 23.1 & 17.1 & 17.0 & 1.7 \\
\hline \multicolumn{7}{|c|}{ Protein source, $\%$ of diet $\mathrm{CP}$} \\
\hline Soybean meal & 126 & 0.5 & 61.7 & 28.9 & 28.2 & 14.0 \\
\hline Heated soybean meal $^{3}$ & 20 & 11.3 & 60.3 & 40.8 & 35.2 & 12.7 \\
\hline Extruded soybean meal & 3 & 18.1 & 24.1 & 18.1 & 20.1 & 3.4 \\
\hline Corn gluten meal & 24 & 2.9 & 56.4 & 22.6 & 25.4 & 17.1 \\
\hline Fish meal & 19 & 6.3 & 34.4 & 15.2 & 16.1 & 7.2 \\
\hline Animal meal & 48 & 1.1 & 58.0 & 10.6 & 13.7 & 11.9 \\
\hline $\mathrm{N}$ intake, g/d & 224 & 264 & 855 & 527 & 531 & 120.8 \\
\hline \multicolumn{7}{|l|}{ Flow to small intestine, $\mathrm{g} / \mathrm{d}$} \\
\hline Total N & 208 & 198 & 930 & 545 & 537 & 126.8 \\
\hline NAN & 207 & 173 & 858 & 507 & 502 & 117.4 \\
\hline Microbial N & 224 & 100 & 484 & 259 & 271 & 81.1 \\
\hline NANMN $^{4}$ & 221 & 61 & 576 & 234 & 237 & 87.1 \\
\hline Endogenous $\mathrm{N}^{5}$ & 224 & 20.5 & 50.9 & 37.2 & 37.1 & 6.5 \\
\hline Total AA & 106 & 917 & 4113 & 2778 & 2610 & 630 \\
\hline $\mathrm{EAA}^{6}$ & 104 & 440 & 1970 & 1281 & 1218 & 302 \\
\hline Lys & 108 & 58 & 264 & 167 & 168 & 48 \\
\hline Met & 103 & 16 & 83 & 50 & 50 & 15 \\
\hline OMTD,${ }^{7} \mathrm{~kg} / \mathrm{d}$ & 177 & 5.1 & 15.4 & 9.2 & 9.3 & 2.0 \\
\hline
\end{tabular}

${ }^{1}$ All data were taken or calculated from experiments reported in 57 independent studies (Kung et al., 1983; Stern et al., 1983; Prange et al., 1984; Robinson and Sniffen, 1984; Santos et al., 1984; Robinson et al., 1985; Rode et al., 1985; Stern et al., 1985; Armentano et al., 1986; Lu et al., 1988; Price et al., 1988; McCarthy et al., 1989; Waltz et al., 1989; Herrera-Saldana et al., 1990; King et al., 1990; Klusmeyer et al., 1990, 1991a,b; Cameron et al., 1991; Lynch et al., 1991; Ohajuruka et al., 1991; Stokes et al., 1991; Erasmus et al., 1992, 1994; Aldrich et al., 1993; Christensen et al., 1993a, 1996; Cunningham et al., 1993, 1994, 1996; Feng et al., 1993; Poore et al., 1993; Tice et al., 1993; Benchaar et al., 1994; Mansfield and Stern, 1994; Pantoja et al., 1994, 1995; Calsamiglia et al., 1995; Oliveira et al., 1995; Overton et al., 1995; Yoon and Stern, 1996; Chan et al., 1997; Kalscheur et al., 1997a,b; Pires et al., 1997; Putnam et al., 1997; Yang et al., 1997; Zhu et al., 1997; Knowlton et al., 1998; O’Mara et al., 1998; Younker et al., 1998; Beauchemin et al., 1999; Ahvenjärvi et al., 2002; Ipharraguerre et al., 2002; Oba and Allen, 2003; Reynal et al., 2003; Voelker and Allen, 2003). Contributions of supplemental protein to dietary CP were estimated using the ingredient composition of experimental diets and the CP content of the protein sources either reported in the corresponding study or tabulated by NRC (2001).

${ }^{2}$ Number of treatment comparisons.

${ }^{3}$ Nonenzymatically browned soybean meal.

${ }^{4}$ Nonammonia nonmicrobial N.

${ }^{5}$ All data were calculated as DMI $(\mathrm{kg} / \mathrm{d}) \times 1.9(\mathrm{NRC}, 2001)$.

${ }^{6}$ Essential amino acids.

${ }^{7}$ Organic matter truly digested in the rumen.

Weighted means and 95\% confidence intervals were calculated for each group of treatment comparisons using sample size and variation within and across (random) studies as weighting factors. Results are reported as the mean percentage change, which is equal to (response ratio -1$) \times 100$. If there were no differences between the control and RUP experimental diets, then the response for the control and RUP experimental diets would be the same and the response ratio would be equal to 1 and the mean percentage change would equal 0 . If the response was greater for feeding RUP, then the response ratio would be $>1$ and the mean percentage change would be $>0$ or positive. If the response was less for RUP, then the response ratio would be $<1$ and the mean percentage change would be $<0$ or negative. In the figures, symbols represent the mean percentage change, the bars represent the $95 \%$ confidence interval, and the number in parentheses is the number of treatment comparisons. If the $95 \%$ confidence interval bar does not overlap 0 , then the mean percentage change is different from $0(\alpha=0.05)$. If the 95\% confidence interval bars for the RUP supplements do not overlap, then they are significantly different $(\alpha=$ 0.05 ) from each other.

\section{Nitrogen Passage to the Small Intestine}

Criteria required for a study to be included in the data set for $\mathrm{N}$ passage to the small intestine were 1) lactating cows had to be fed ad libitum; 2) the methodology had to be described and a minimum of 8 samples had to be collected within at least a 48 -h period from 


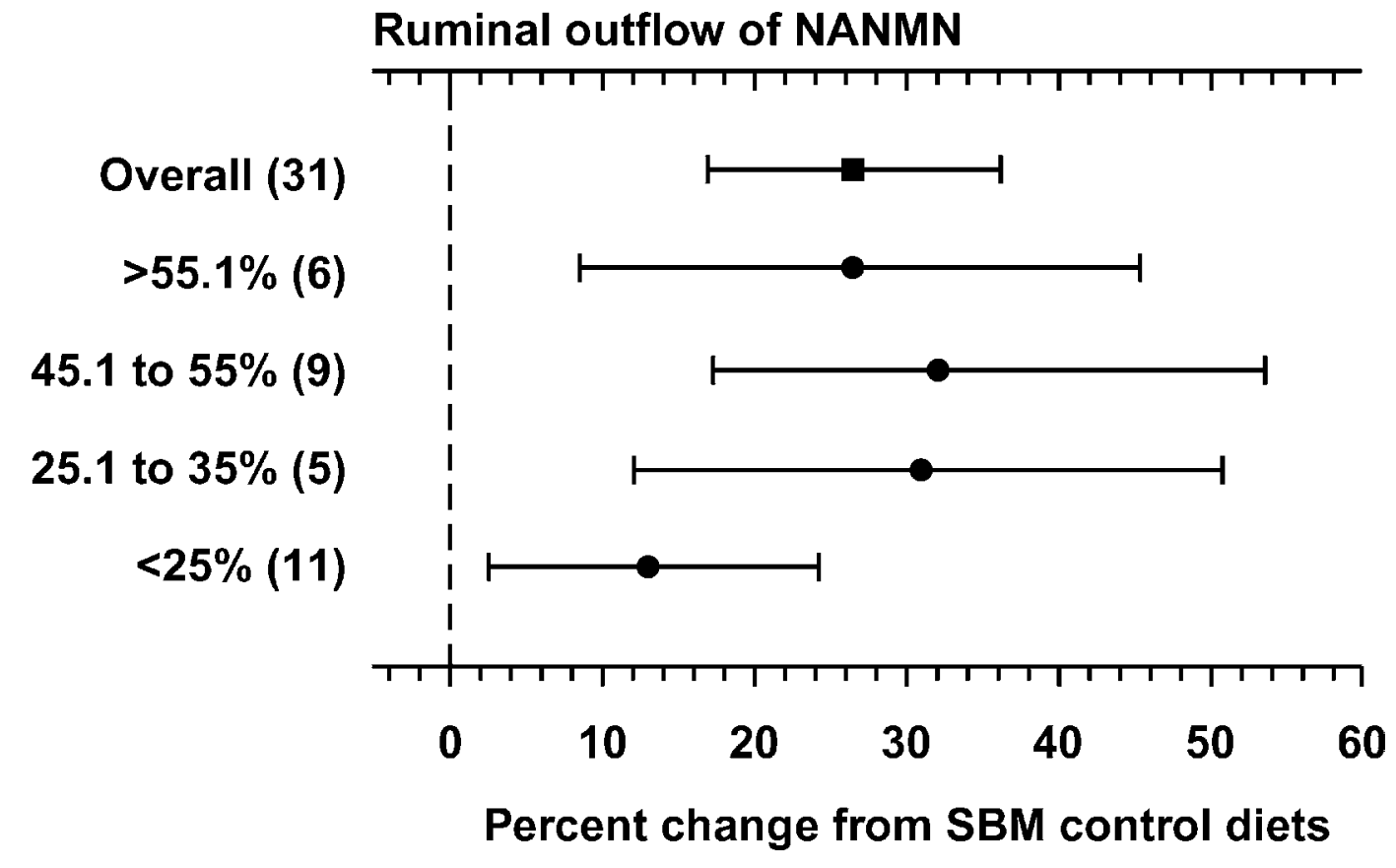

Figure 1. Effect of the proportion of dietary CP supplied from supplemental RUP sources in experimental diets compared with solventextracted soybean meal (SBM) control diets on nonammonia, nonmicrobial N (NANMN) flow from the rumen of lactating dairy cows. Means $\pm 95 \%$ confidence intervals ( $n$; number of treatment comparisons) are shown.

the omasum or duodenum; 3) external markers had to be used to estimate digesta flow; and 4) means with standard errors or standard deviations had to be reported.

An $\mathrm{N}$ flow data set of 57 research trials (Table 1) provided a maximum of 224 treatment comparisons. Dry matter intake ranged from 10.8 to $26.8 \mathrm{~kg} / \mathrm{d}$, and dietary CP ranged from 11.3 to $23.1 \%$. Only treatment comparisons that were isonitrogenous were included in the data set. The data set contained a wide range of values for passage of total N; NAN; microbial N; nonammonia, nonmicrobial N (NANMN); Lys; and Met. The mean and median for these parameters were very similar, indicating that approximately the same number of observations was either less than or greater than the treatment mean.

Regression analysis revealed a linear relationship between $\mathrm{N}$ intake and passage of NAN to the small intestine of lactating dairy cows fed unrestricted amounts of feed [NAN flow, $\mathrm{g} / \mathrm{d}=147(\mathrm{SE} 35.4, P<0.01)+0.676$ $\times \mathrm{N}$ intake (SE $\left.0.06, P<0.01) ; \mathrm{R}^{2}=0.74\right]$. These findings indicate that the amount of $\mathrm{N}$ consumed by cows dictates a part, but not all, of the variation in passage of NAN to the small intestine, which agrees with the conclusions of Clark et al. (1992).

Data from the meta-analysis indicated that feeding the supplemental RUP sources increased $(P<0.05)$ passage of NAN to the small intestine if soybean meal
(SBM), other plant proteins, or casein were used as the protein supplements in the control diets. However, if a source of supplemental RUP was in the control diet, then supplemental RUP in the experimental diet had no effect on NAN flow from the rumen (data not shown). These data also indicate that supplemental RUP in the experimental diet provided larger increases $(P<0.05)$ in NAN outflow when control diets contained casein rather than SBM (+25 vs. $+7 \%)$. Therefore, the source of CP in the control diet to which the supplemental RUP in the experimental diet was compared had a significant effect $(P<0.05)$ on the magnitude of the response obtained from the RUP source. Because SBM was the most frequently used CP supplement in the control diets, and because SBM is widely used for feeding dairy cows, other $\mathrm{N}$ flow data in this paper will focus on the comparison between RUP experimental treatments and control diets that contain SBM.

Figure 1 shows the effects of including different proportions of $\mathrm{CP}$ in the experimental diets from supplemental RUP sources on ruminal outflow of NANMN compared with SBM control diets. All ratios of supplemental RUP inclusion increased the escape of NANMN from the rumen. The overall effect was a $26 \%$ increase $(P<0.05)$ in ruminal outflow of NANMN. The supplemental RUP increased the escape of NANMN from the rumen at all percentages of inclusion in the experimental diet. The smallest mean magnitude of response was 


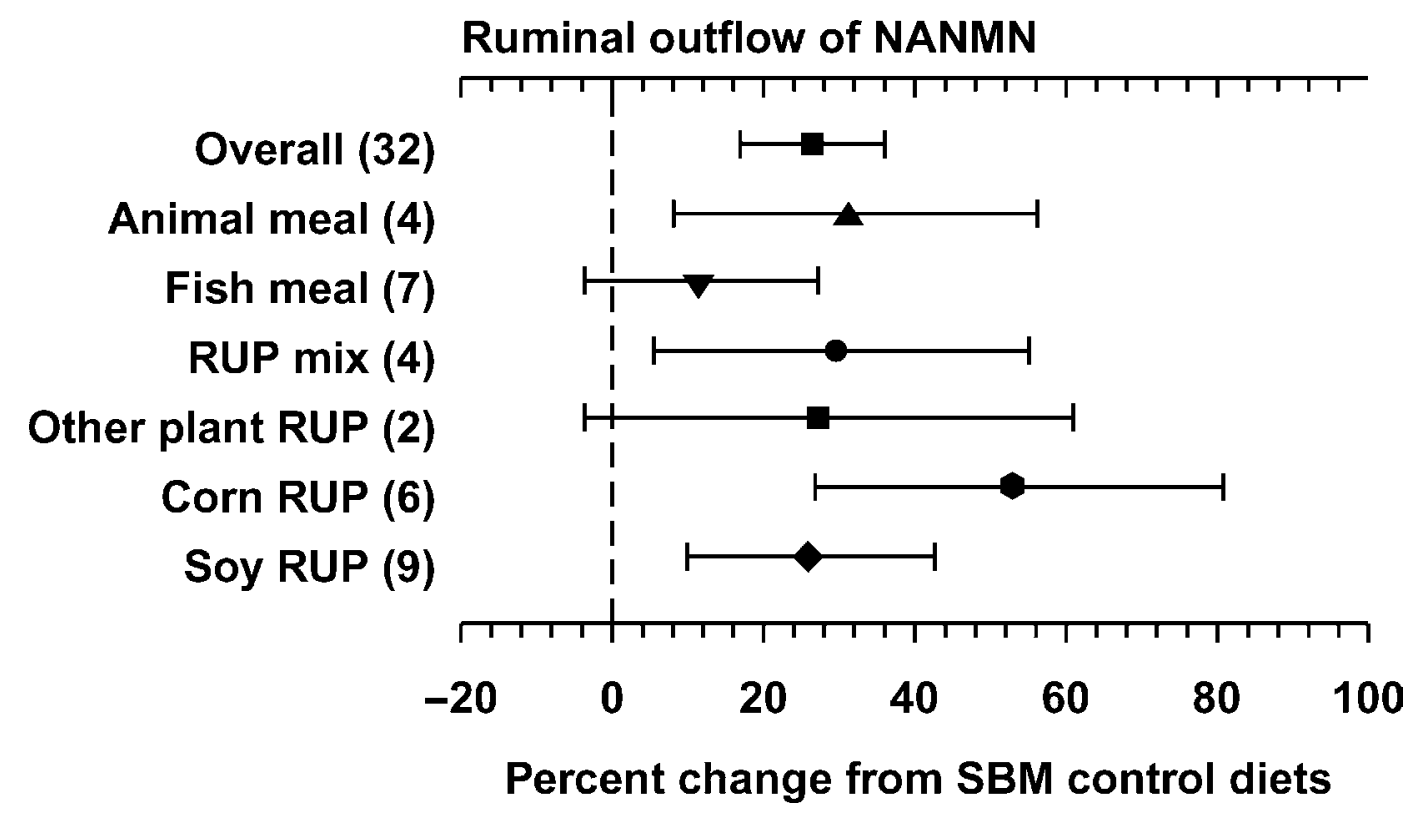

Figure 2. Effect of source of RUP supplement in experimental diets compared with solvent-extracted soybean meal (SBM) control diets on nonammonia, nonmicrobial N (NANMN) flow from the rumen of lactating dairy cows. Means $\pm 95 \%$ confidence intervals $(n)$ are shown.

at the $<25 \%$ concentration of RUP in the experimental diet, which is the concentration that most closely represents practical feeding recommendations of RUP supplements for lactating dairy cows. Although confidence intervals were too large to draw statistical inferences among proportions of supplemental RUP in the diet, it appears that the magnitude of the response to increasing proportions of supplemental RUP is not linear.

The mean response for each source of supplemental RUP showed that treated soy products, corn by-products, a mixture of animal, marine, and/or plant proteins (RUP mix), and animal meal increased $(P<0.05)$ the amount of NANMN delivered to the small intestine compared with SBM control diets (Figure 2). Other protected plant proteins and fish meal also increased passage of NANMN to the small intestine, but the response was not significant. These findings agree with other reports (Clark et al., 1992; Santos et al., 1998b) that some RUP supplements increase passage of NANMN to the small intestine of lactating dairy cows. The magnitude of the mean increase in passage of NANMN to the small intestine caused by the different sources of supplemental RUP ranged from about 12 to $52 \%$, and the average for all sources of RUP was more than $20 \%$. Even though this is a wide range in response, insufficient data resulted in large confidence intervals that did not allow for detection of differences among sources of supplemental RUP.

In contrast to the positive overall effect that the RUP supplements had on passage of NANMN to the small intestine, there was a 7\% depression $(P<0.05)$ in the overall response to RUP supplements on passage of microbial $\mathrm{N}$ to the small intestine (Figure 3). These data support the conclusions of Hoover and Stokes (1991), Clark et al. (1992), and Firkins (1996) that a shortage of energy, AA, peptides, or ammonia in the rumen can depress the growth of ruminal bacteria when RDP sources are replaced with RUP supplements. Animal meal, fish meal, and RUP mix depressed $(P<0.05)$ ruminal outflow of microbial $\mathrm{N}$ by 10 to $14 \%$. There was also a mean decrease of 6 to $8 \%$ in ruminal outflow of microbial $\mathrm{N}$ caused by corn by-products and other protected plant sources, and a mean increase of $2 \%$ for treated soy products, but these differences were not significant compared with the SBM control diets. Therefore, feeding the supplemental sources of RUP increased $(P<0.05)$ the intestinal supply of NANMN (i.e. feed plus endogenous protein) but decreased $(P<0.05)$ the intestinal supply of microbial $\mathrm{N}$ compared with SBM.

The overall mean for ruminal outflow of NAN was increased $(P<0.05)$ about $6 \%$ when experimental diets that contained RUP were compared with SBM control diets (Figure 4). Compared with SBM control diets, experimental diets that contained treated soy products, corn by-products, and RUP mix increased $(P<0.05)$ ruminal outflow of NAN. Other protected plant proteins and fish meal did not increase ruminal outflow of NAN. Animal meal increased ruminal outflow of NAN by 


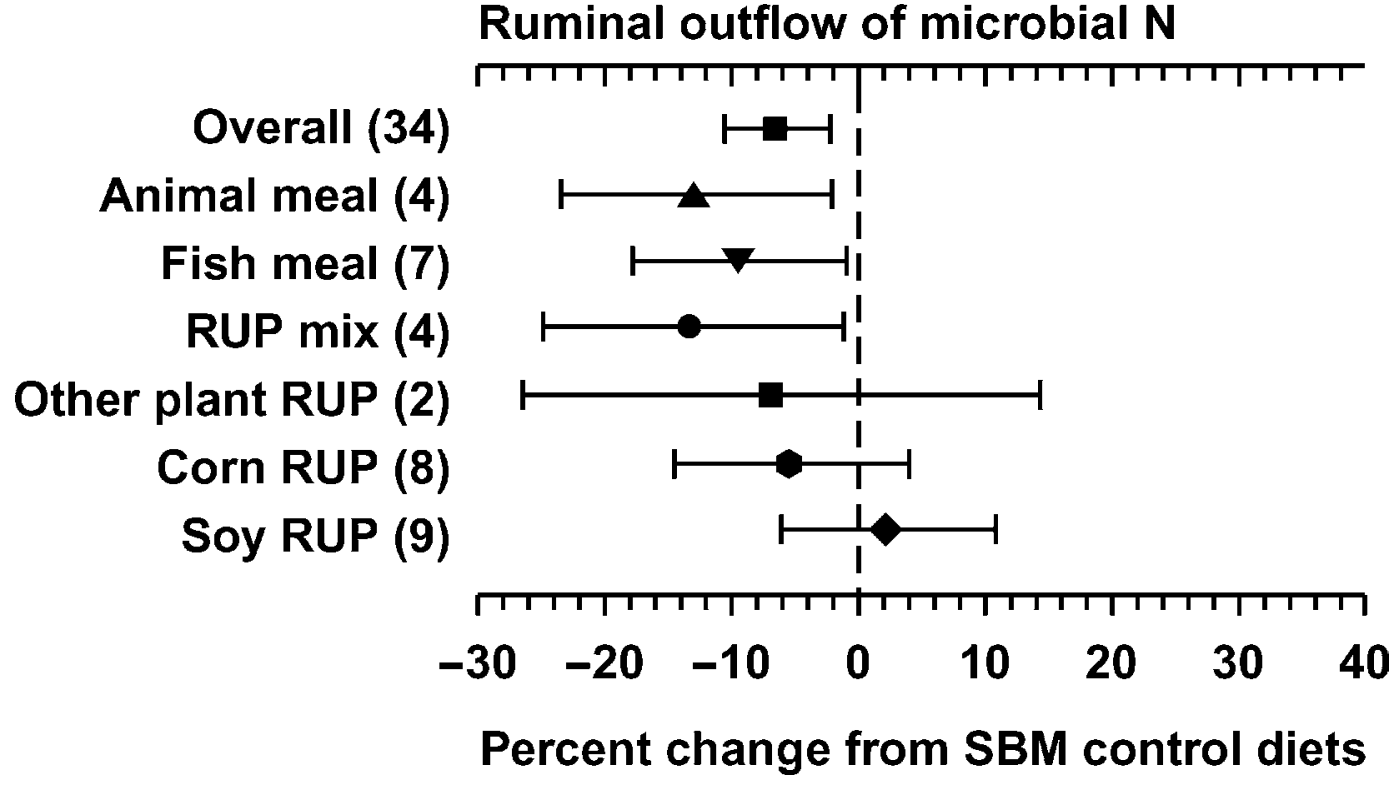

Figure 3. Effect of source of RUP supplement in experimental diets compared with solvent-extracted soybean meal (SBM) control diets on microbial $\mathrm{N}$ flow from the rumen of lactating dairy cows. Means $\pm 95 \%$ confidence intervals $(n)$ are shown.

about $5 \%$ compared with SBM, but this increase was not significant. Overlapping of the $95 \%$ confidence interval bars indicates that the ruminal outflow of NAN was not different among sources of supplemental RUP.

Across all comparisons, the ruminal outflow of essential amino acids (EAA) also was quantitatively improved by $9 \%$ when RUP supplements were compared with SBM (Figure 5). All RUP supplements caused a positive response, but only the response to blood meal, RUP mix, and corn by-products was significant, ranging from 12 to $16 \%$. Therefore, these data suggest that the benefit of the greater ruminal outflow of NANMN elicited by most RUP supplements was greater than their detrimental effects on ruminal outflow of microbial $\mathrm{N}$.

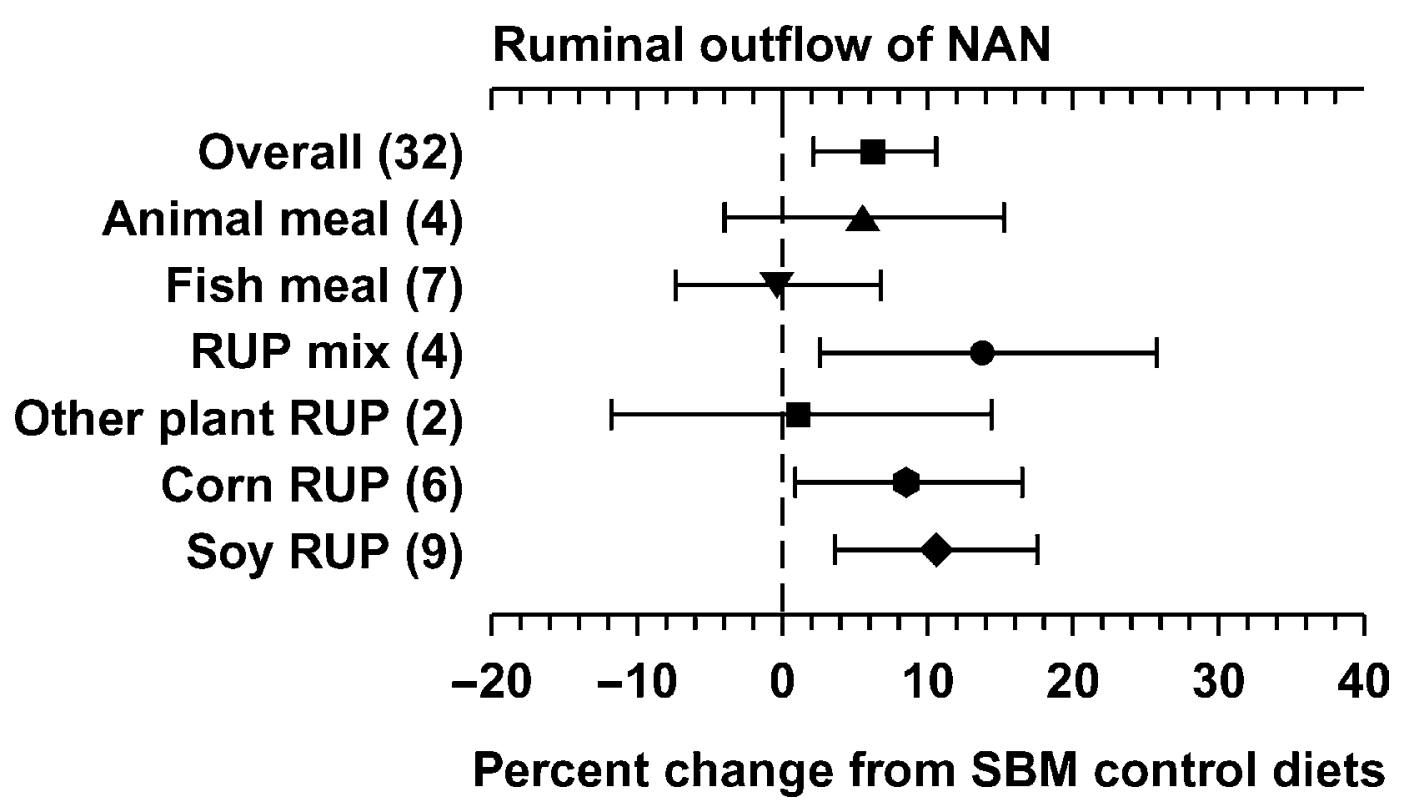

Figure 4. Effect of source of RUP supplement in experimental diets compared with solvent-extracted soybean meal (SBM) control diets on NAN flow from the rumen of lactating dairy cows. Means $\pm 95 \%$ confidence intervals $(n)$ are shown. 


\section{Ruminal outflow of essential AA}

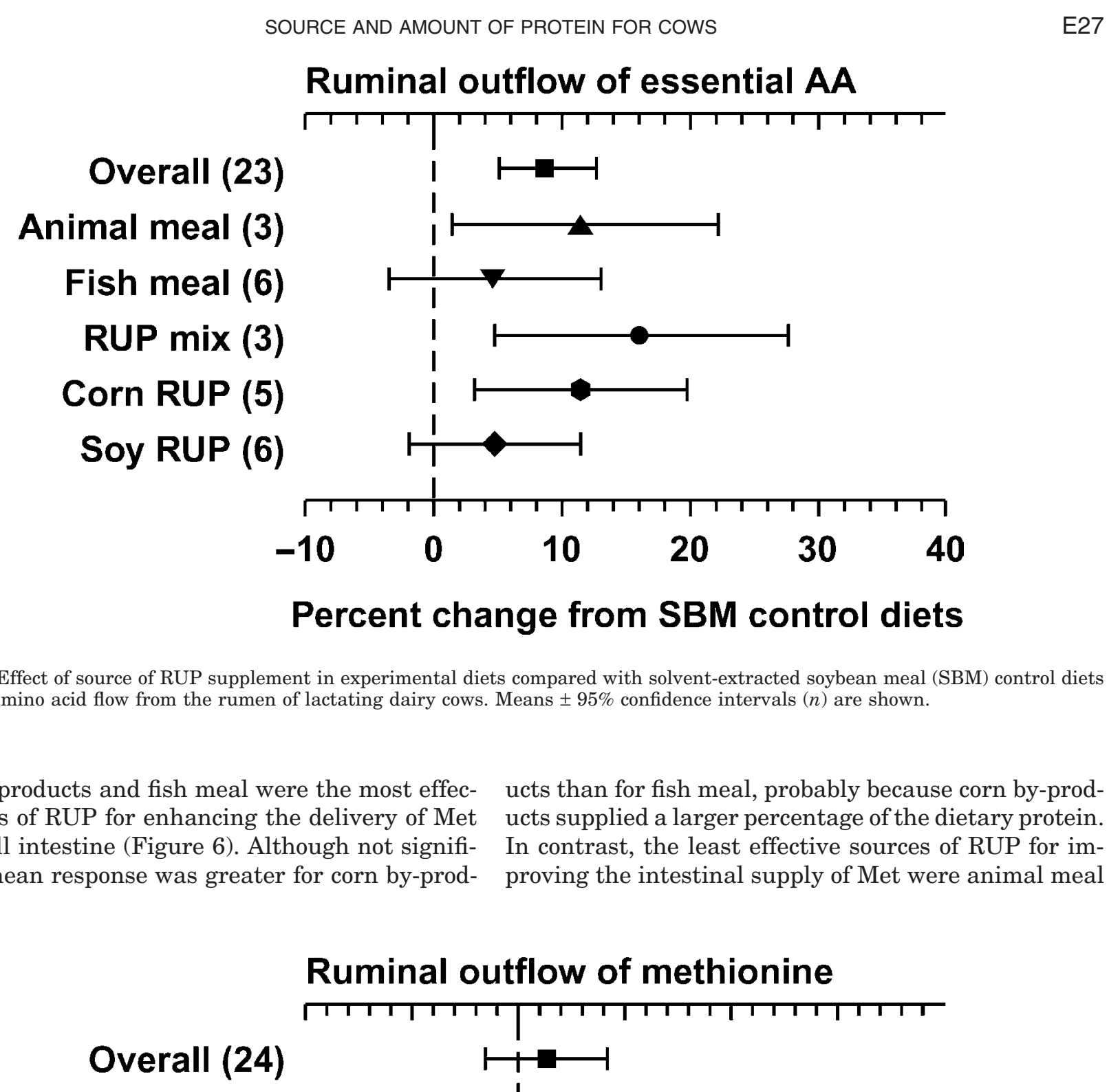

Figure 5. Effect of source of RUP supplement in experimental diets compared with solvent-extracted soybean meal (SBM) control diets on essential amino acid flow from the rumen of lactating dairy cows. Means $\pm 95 \%$ confidence intervals $(n)$ are shown.

Corn by-products and fish meal were the most effective sources of RUP for enhancing the delivery of Met to the small intestine (Figure 6). Although not significant, the mean response was greater for corn by-prod- ucts than for fish meal, probably because corn by-products supplied a larger percentage of the dietary protein. In contrast, the least effective sources of RUP for improving the intestinal supply of Met were animal meal
Overall (24)

Animal meal (3)

Fish meal (6)

RUP mix (4)

Corn RUP (5)

Soy RUP (6)

\section{Ruminal outflow of methionine}

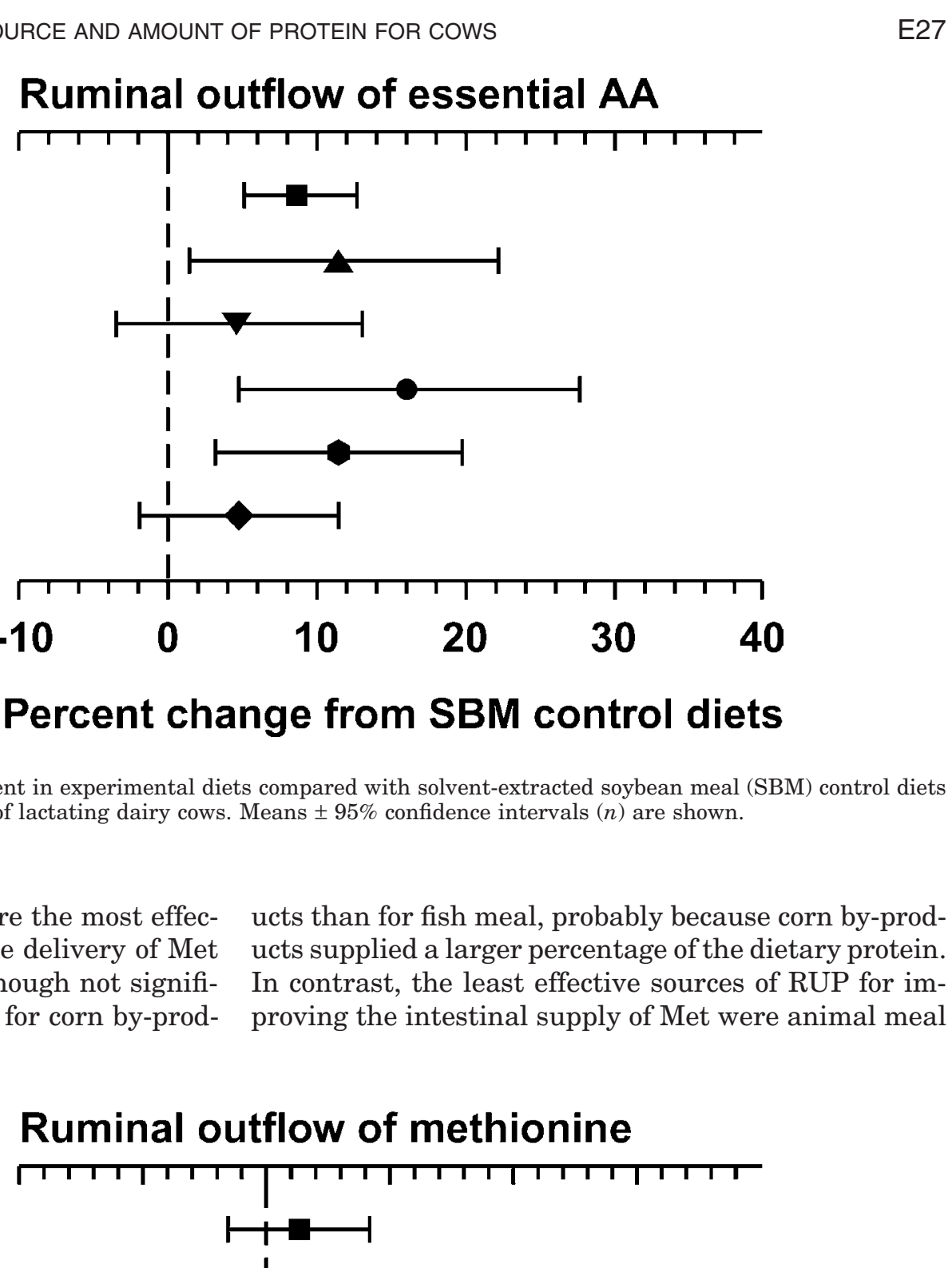




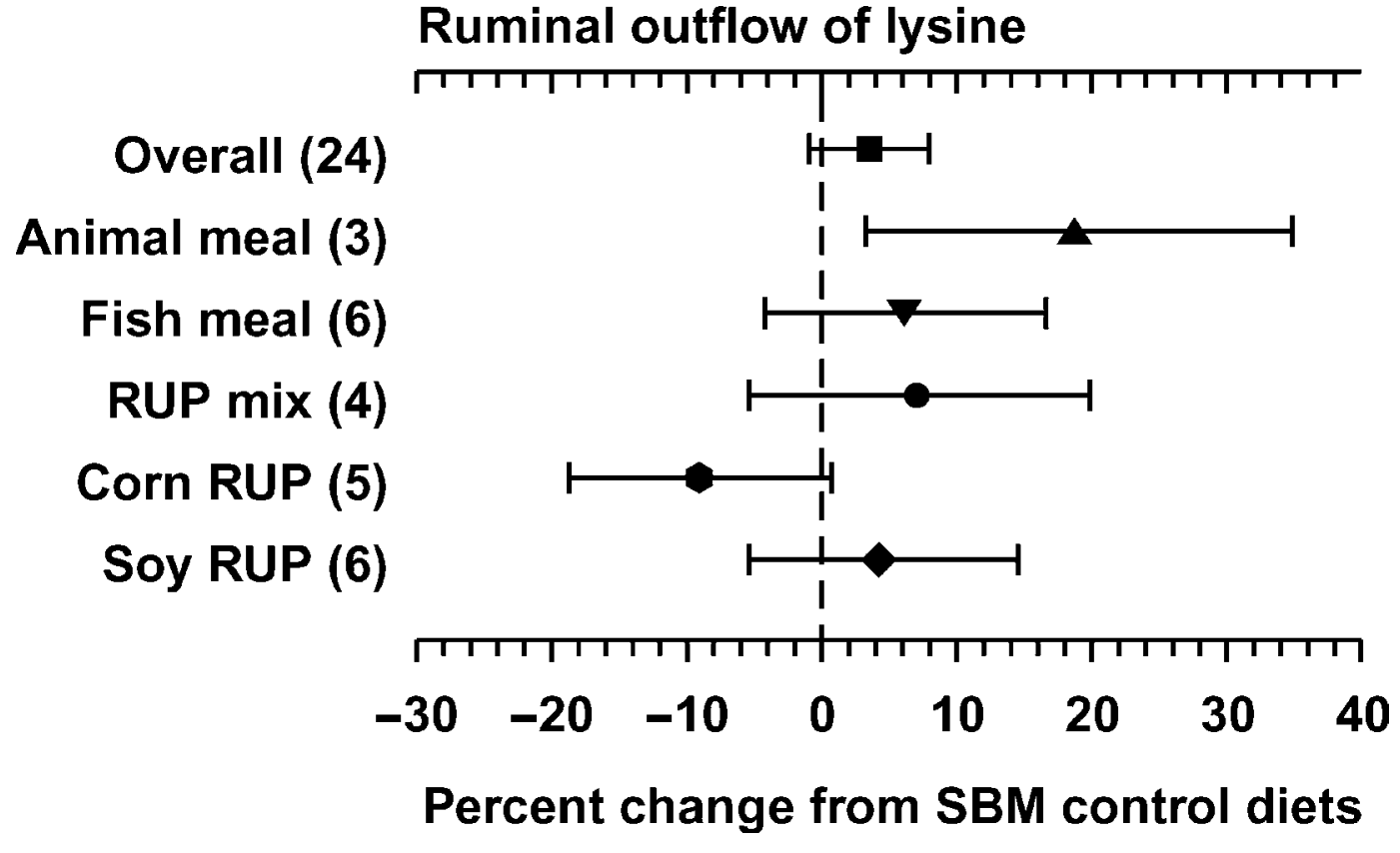

Figure 7. Effect of source of RUP supplement in experimental diets compared with solvent-extracted soybean meal (SBM) control diets on lysine flow from the rumen of lactating dairy cows. Means $\pm 95 \%$ confidence intervals $(n)$ are shown.

and treated soy products. One of the most distinctive differences among these RUP supplements is Met content, which is greater for corn and fish proteins than for animal and soy proteins (NRC, 2001). Therefore, the amount and source of RUP in the diet and the Met content of the RUP affects the ruminal outflow of Met.

The largest positive mean increase for the ruminal outflow of Lys was obtained with animal meal (Figure 7), which has one of the highest concentrations of Lys among these RUP supplements (NRC, 2001). In contrast, the largest mean decrease was for corn by-products that contain a low concentration of Lys (NRC, 2001). Responses to fish meal, RUP mix, and treated soy proteins were intermediate between animal meal and corn by-products. As was observed for Met, the amount and source of RUP in the diet and the Lys content of the RUP supplement affects the ruminal outflow of Lys.

These data indicate that there are at least 5 factors that affect the magnitude of the effect on ruminal outflow of AA in response to feeding RUP sources to dairy cows in research trials. These factors are the source of $\mathrm{CP}$ in control diet, proportion and source of RUP in experimental diet, effect of RUP on ruminal outflow of microbial protein, degradability of the RUP source, and the AA content of RUP outflow from rumen.

\section{Performance of Lactating Dairy Cows}

Underfeeding or overfeeding CP to dairy cows can have detrimental effects on milk production, efficiency of nutrient utilization, reproduction, the environment, and the overall profit of the dairy operation (NRC, 2001; CAST, 2002). Therefore, the factorial effects of the amount and source of CP fed to dairy cows must be understood if we are to optimize productivity and maximize nutrient utilization.

The effect that the availability and source of protein have on productive performance of dairy cows was examined by creating a data set from published studies designed to investigate the response of lactating cows to changes in the amount and/or source of dietary CP. Studies were included in the data set only when cows were fed ad libitum, the CP percentage of the diet was reported or could be estimated, the experimental design was adequately described, DMI and DIM were reported, and means plus standard error or standard deviation for response variables were provided.

The data set (Table 2) contained results from 112 research trials in which cows were fed TMR (88 studies) or forage and concentrate separately ( 24 studies). In most cases, experiments started when cows were in early lactation and ended when cows were either in early or mid-lactation. Dry matter intake ranged from 10.2 to $29.4 \mathrm{~kg} / \mathrm{d}$, and CP in DM ranged from 12.1 to $25.8 \%$. Milk yield varied from 15 to $46 \mathrm{~kg} / \mathrm{d}$. Maximum milk $\mathrm{CP}$ and fat yields were about 3 times greater than minimum yields. Mean and median values were similar for all variables in this data set.

A significant curvilinear relationship $\left(R^{2}=0.19\right)$ was found between milk yield and the concentration of $\mathrm{CP}$ 
Table 2. Descriptive statistics of the performance data set ${ }^{1}$.

\begin{tabular}{lcclllc}
\hline Item & $n^{2}$ & Minimum & Maximum & Median & Mean & SD \\
\hline Number of cows/treatment & $4732^{3}$ & 4 & 75 & 12 & 13 & 10 \\
CP, \% of dietary DM & 560 & 12.1 & 25.8 & 17.2 & 17.2 & 2.3 \\
DMI, kg/d & 560 & 10.2 & 29.4 & 21.1 & 21.0 & 3.2 \\
Milk yield, kg/d & 558 & 15.1 & 46.2 & 31.7 & 31.5 & 5.9 \\
Milk CP content, \% & 547 & 2.54 & 3.70 & 3.07 & 3.08 & 0.20 \\
Milk CP yield, kg/d & 402 & 0.53 & 1.50 & 1.00 & 0.98 & 0.17 \\
Milk fat content, \% & 543 & 2.08 & 5.12 & 3.45 & 3.43 & 0.44 \\
Milk fat yield, kg/d & 403 & 0.62 & 1.76 & 1.12 & 1.11 & 0.20 \\
\hline
\end{tabular}

${ }^{1}$ All data were taken or calculated from experiments reported in 112 independent studies (Barney et al., 1981; Mielke and Schingoethe, 1981; van Dijk et al., 1983; Henderson et al., 1985; Polan et al., 1985, 1997; Van Horn et al., 1985; Broderick, 1986, 1992, 2003; Lundquist et al., 1986; Annexstad et al., 1987; Garnsworthy and Jones, 1987; Howard et al., 1987; Jaquette et al., 1987; Kaim et al., 1987; Bowman et al., 1988; Hadsell and Sommerfeldt, 1988; Jones and Garnsworthy, 1988; Léonard and Block, 1988; Manson and Leaver, 1988; Robinson and Kennelly, 1988; Schingoethe et al., 1988; Sloan and Rowlinson, 1988; Voss et al., 1988; Bruckental et al., 1989, 2000; De Gracia et al., 1989; Garnsworthy, 1989; Herrera-Saldana and Huber, 1989; Higginbotham et al., 1989; Mäntysaari et al., 1989; Blauwiekel et al., 1990; Broderick et al., 1990, 1993; Canfield et al., 1990; Casper et al., 1990, 1999; Cody et al., 1990; Lees et al., 1990; McGuffey et al., 1990; Small and Gordon, 1990; Hoffman et al., 1991; Kim et al., 1991; Knapp et al., 1991; Owen and Larson, 1991; Petit and Veira, 1991; Robinson et al., 1991; Windschitl, 1991; Winsryg et al., 1991; Wohlt et al., 1991; Zimmerman et al., 1991, 1992; Atwal and Erfle, 1992; Calsamiglia et al., 1992; Grings et al., 1992; Harris et al., 1992; Nakamura et al., 1992; Aharoni et al., 1993; Armentano et al., 1993; Chen et al., 1993; Christensen et al., 1993b, 1994; Dhiman and Satter, 1993; Keery and Amos, 1993; Roseler et al., 1993; Grummer et al., 1994, 1996; Mansfield et al., 1994; Palmquist and Weiss, 1994; Robinson and McQueen, 1994; Tomlinson et al., 1994; Wattiaux et al., 1994; Atwal et al., 1995; Baker et al., 1995, 1996; ColinSchoellen et al., 1995; Powers et al., 1995; Spain et al., 1995; Wheeler et al., 1995; Cunningham et al., 1996; Khorasani et al., 1996; Lines and Weiss, 1996; Pires et al., 1996; Son et al., 1996; Bernard, 1997; Dhiman et al., 1997; Henson et al., 1997; Komaragiri and Erdman, 1997; Maiga and Schingoethe, 1997; Rodriguez et al., 1997; Titgemeyer and Shirley, 1997; Weigel et al., 1997; Garcia-Bojalil et al., 1998; Grant and Haddad, 1998; Hongerholt and Muller, 1998; Nichols et al., 1998; Overton et al., 1998; Santos et al., 1998a; Kalscheur et al., 1999; McCormick et al., 1999; Mabjeesh et al., 2000; Wu and Satter, 2000; Abu-Ghazaleh et al., 2001; Bargo et al., 2001; McCormick et al., 2001; Allison and Garnsworthy, 2002; Davidson et al., 2003; Leonardi et al., 2003, Noftsger and St-Pierre, 2003; Reynal and Broderick, 2003). Dietary CP was taken as reported or estimated using the ingredient composition of experimental diets and the CP content of the ingredients either reported in the corresponding study or tabulated by NRC (2001).

${ }^{2}$ Number of comparisons.

${ }^{3}$ Total number of cows used in the data set.

in the diet (Figure 8). Diminishing returns in milk production to increases in dietary CP is a widely documented response. The multivariate regression analysis conducted by the 2001 NRC Dairy Committee resulted in an equation that predicts responses in milk production of $0.75 \mathrm{~kg} / \mathrm{d}$ when CP increased from 15 to $16 \%$ and $0.35 \mathrm{~kg} / \mathrm{d}$ when CP increased from 19 to $20 \%$. Maximum milk yield is achieved at $23 \% \mathrm{CP}$ in the diet. Using a larger data set and different methodology, estimations derived from the equation in this plot predict an increase of 0.94 and $0.42 \mathrm{~kg} / \mathrm{d}$ when dietary $\mathrm{CP}$ is increased from 15 to 16 and 19 to $20 \%$, respectively. Similarly, maximum milk production is achieved at $22.8 \%$ CP. These results are similar to results reported by NRC (2001).

Considerable variation in the relationship between the percentage of dietary $\mathrm{CP}$ and milk yield might be accounted for by the source of CP. To test this hypothesis, the data set was divided into 2 smaller data sets. The first data set contained 193 comparisons in which supplemental CP was provided entirely from SBM. The second data set contained 149 comparisons in which supplemental CP was supplied partially from animal, marine, or blends of these 2 protein sources. A quadratic relationship provided the best fit for describing the relationship between milk yield and dietary CP percentage for both SBM $\left(R^{2}=0.35\right)$ and the animal/marine proteins $\left(\mathrm{R}^{2}=0.30\right)$. According to the equation for the SBM data set, increasing CP from 14 to $18 \%$ with SBM increased milk $2.7 \mathrm{~kg} / \mathrm{d}$ and milk production was maximized $(32.8 \mathrm{~kg} / \mathrm{d})$ at $21.4 \% \mathrm{CP}$ in the diet. The regression equation for the animal/marine protein data set indicated that increasing $\mathrm{CP}$ in the animal/marine protein diets from 14 to $18 \%$ increased milk yield by 2.9 $\mathrm{kg} / \mathrm{d}$ and yield was maximized $(33.8 \mathrm{~kg} / \mathrm{d})$ at $19.1 \% \mathrm{CP}$ in the diet. These results indicate that the source of $\mathrm{CP}$ contributes variability to the response in milk production explained by changes in dietary $\mathrm{CP}$ percentage.

Ninety-four research trials that provided 244 treatment comparisons were selected from the overall data set, and meta-analyses were used to compare control diets with experimental diets supplemented with RUP 


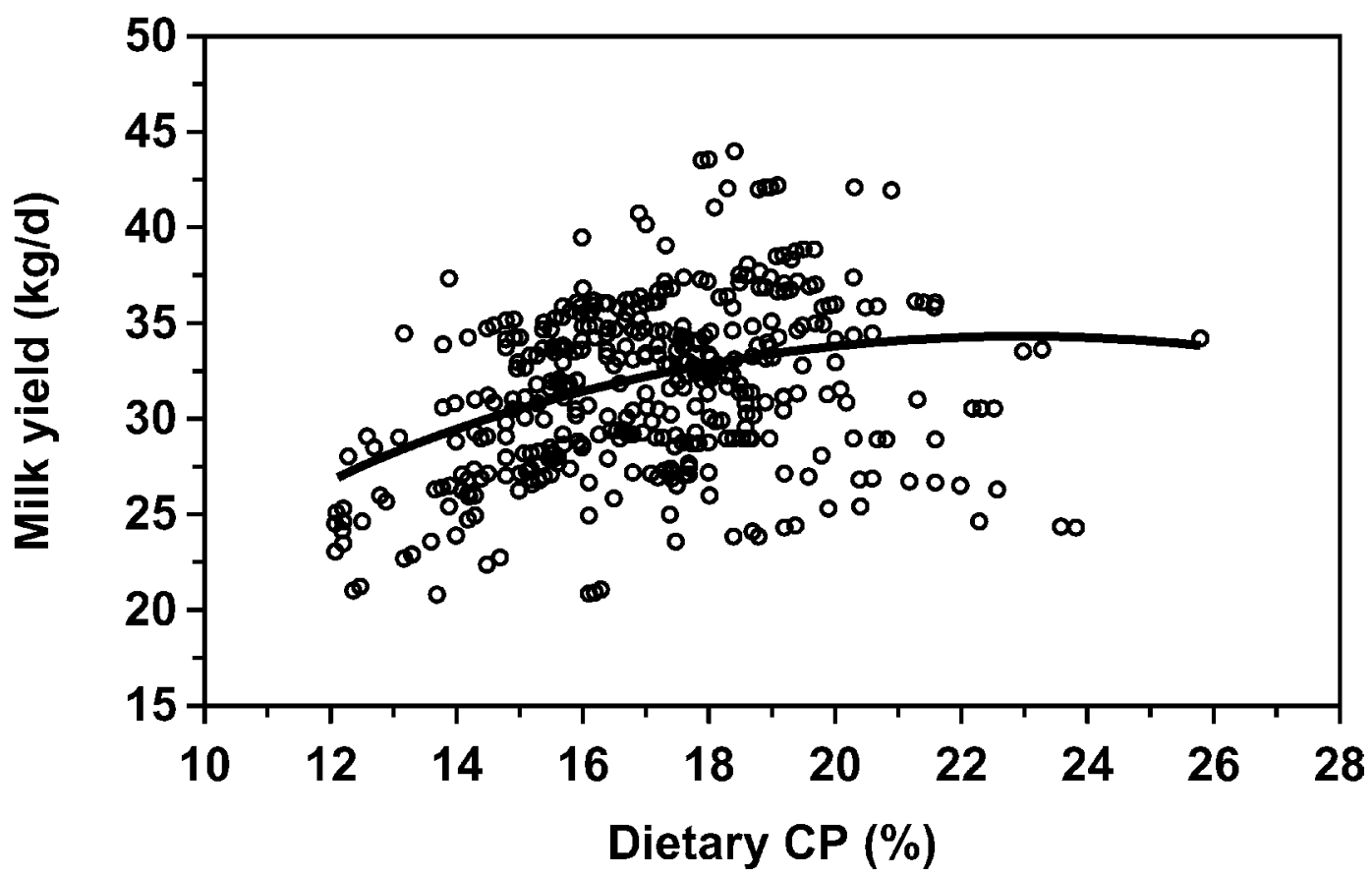

Figure 8. Prediction plot of the relationship between milk yield and dietary CP percentage for lactating dairy cows. A mixed model approach was used based on the assumption of random variation in the effect of study (St-Pierre, 2001). Treatment means were weighted by the reciprocal of the variance of the means (i.e., $\mathrm{n} / \mathrm{s}^{2}$ scaled using the average weight) to account for unequal replications and heterogeneous variances across studies (Oldick et al., 1999). The best-fit model (Milk yield, $\mathrm{kg} / \mathrm{d}=1.04$ [SE 8.91, $P<0.91]+2.92 \times \mathrm{CP} \%$ in the diet [SE $1.00, P<0.004]-0.064 \times \mathrm{CP} \%{ }^{2}$ in the diet [SE $\left.\left.0.028, P<0.02\right] ; \mathrm{R}^{2}=0.19\right)$ was estimated using the Mixed procedure of SAS (SAS Inst., Inc., Cary, NC).

sources. To prevent confounding the effect of the source of $\mathrm{CP}$ with the amount of $\mathrm{CP}$ in the diet, only treatment comparisons that were isonitrogenous were included in this data set. Cows in this data set consumed 14.0 to $29.4 \mathrm{~kg}$ of DM/d, which contained 12.1 to $23.3 \% \mathrm{CP}$. Cows produced 15.1 to $45.5 \mathrm{~kg} / \mathrm{d}$ of milk. The effects of $\mathrm{CP}$ percentage in the diet and the source of CP in the control and experimental diets were used to evaluate variation in cow performance.

Figure 9 shows the effect of CP source in the control diet on the cows' response to RUP supplement source in experimental diets. Although not significant, the magnitude of the mean increase in milk yield when a variety of RUP experimental diets was fed was smallest when the control diet contained SBM. Data suggest that the source of CP in the control diet may influence the mean production response obtained from feeding supplemental RUP in experimental diets in research trials. Because supplemental RUP in experimental diets provided the smallest mean increase in milk yield when SBM control diets were fed, and because SBM also was the most frequently used CP supplement in control diets, data were selected from the overall data set to compare control diets that contained SBM with experimental diets that contained various sources of supplemental RUP. Dry matter intake decreased $(P<$ 0.05 ) when experimental diets that contained fish meal or RUP mix were compared with control diets that contained SBM (Figure 10). Some of the other RUP sources caused a slight increase and others a slight decrease in DMI compared with the SBM control, but these differences were not significant.

Examination of the mean response for RUP supplements that were compared with SBM revealed that fish meal, animal proteins, treated soy products, and RUP mix improved milk production, but the increase was significant only for treated soy products (Figure 11). In contrast, replacing SBM with corn by-products, RUP mix plus urea, and other plant proteins of reduced ruminal degradability tended to depress milk yield, but these differences were not significant. Fish meal and soy products have been suggested to have an AA profile that best resembles milk protein (Santos et al., 1998b; NRC, 2001) and that have high intestinal digestibilities (NRC, 2001). Thus, it appears that the quality of protein, the amount of protein, and the source of protein are major determinants of the milk production response from protein. Compared with the SBM control, treated soy products provided the only increase $(P<0.05)$ in milk yield, and this increase was less than $3 \%$. The 


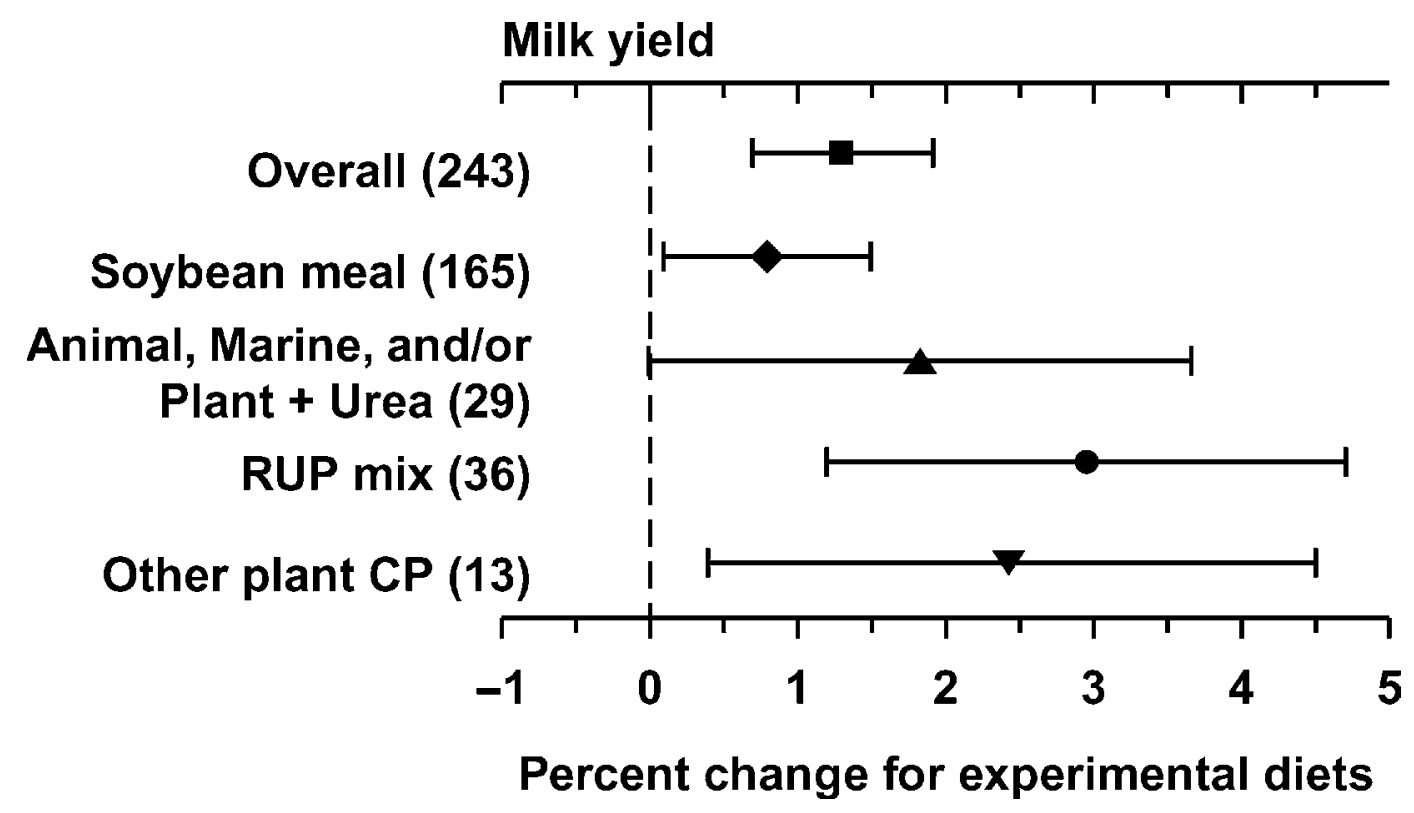

Figure 9. Effect of source of CP in the control diet compared with RUP experimental diets on milk production of dairy cows. Means \pm $95 \%$ confidence intervals $(n)$ are shown.

response to other $\mathrm{CP}$ supplements ranged from $-2.6 \%$ to $+1.4 \%$. The question then becomes if or when is it economical to feed each of these protein supplements. Based on these data, it is apparent that these RUP supplements result in small differences in milk production compared with SBM.

The overall effect of replacing SBM with RUP supplements at the same level of CP in the diet decreased $(P$
$<0.05)$ the percentage of $\mathrm{CP}$ in milk by approximately $2 \%$. Only when fish meal replaced SBM in the diet did the percentage of $\mathrm{CP}$ in milk increase $(0.8 \%)$, but this increase was not significant. Because fish meal decreased $(P<0.05)$ DMI (approximately $2.5 \%)$ and tended to increase milk yield when it replaced SBM in the diet, the trend for fish meal to increase milk CP percentage might be because of increases in the amount

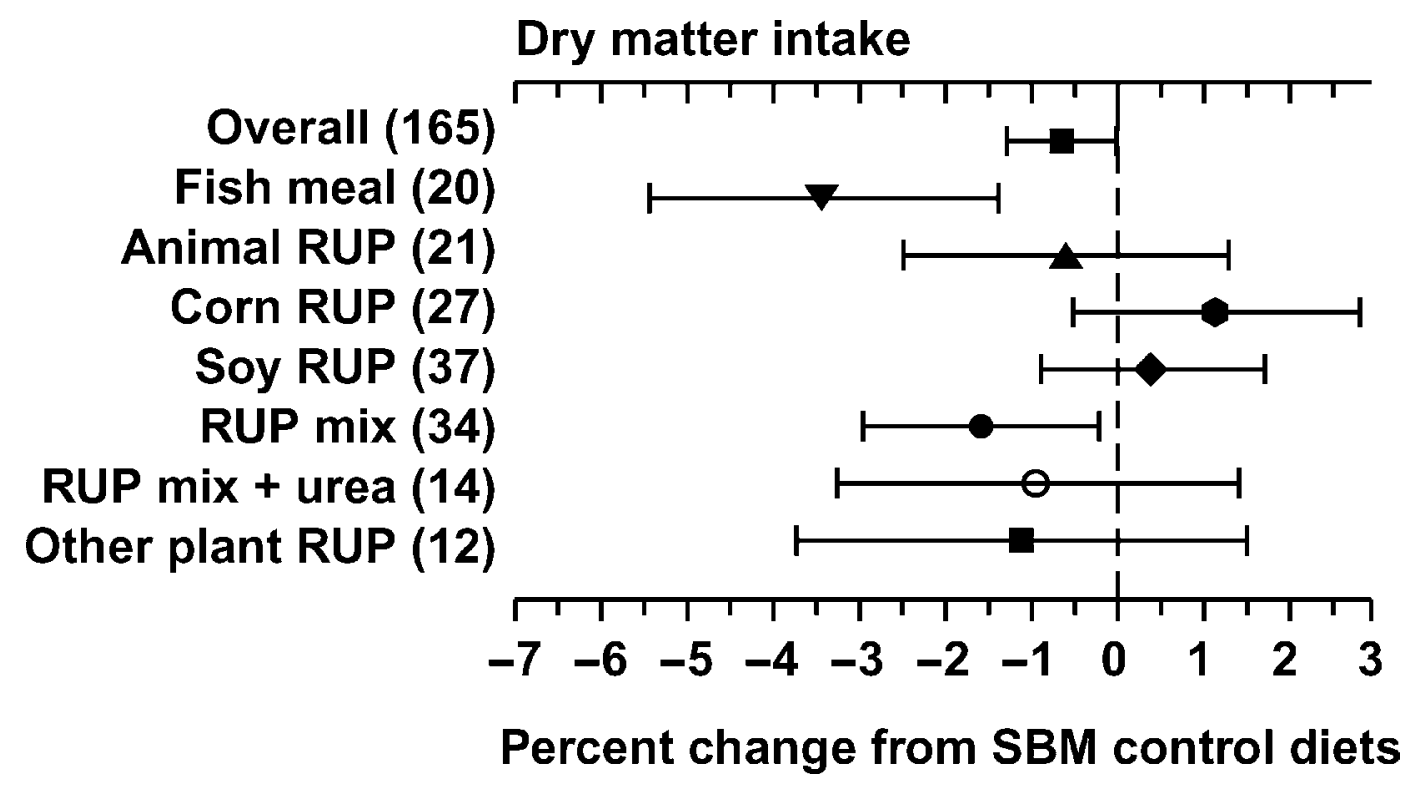

Figure 10. Effect of source of RUP supplement in experimental diets compared with solvent-extracted soybean meal (SBM) control diets on dry matter intake of lactating dairy cows. Means $\pm 95 \%$ confidence intervals $(n)$ are shown. 


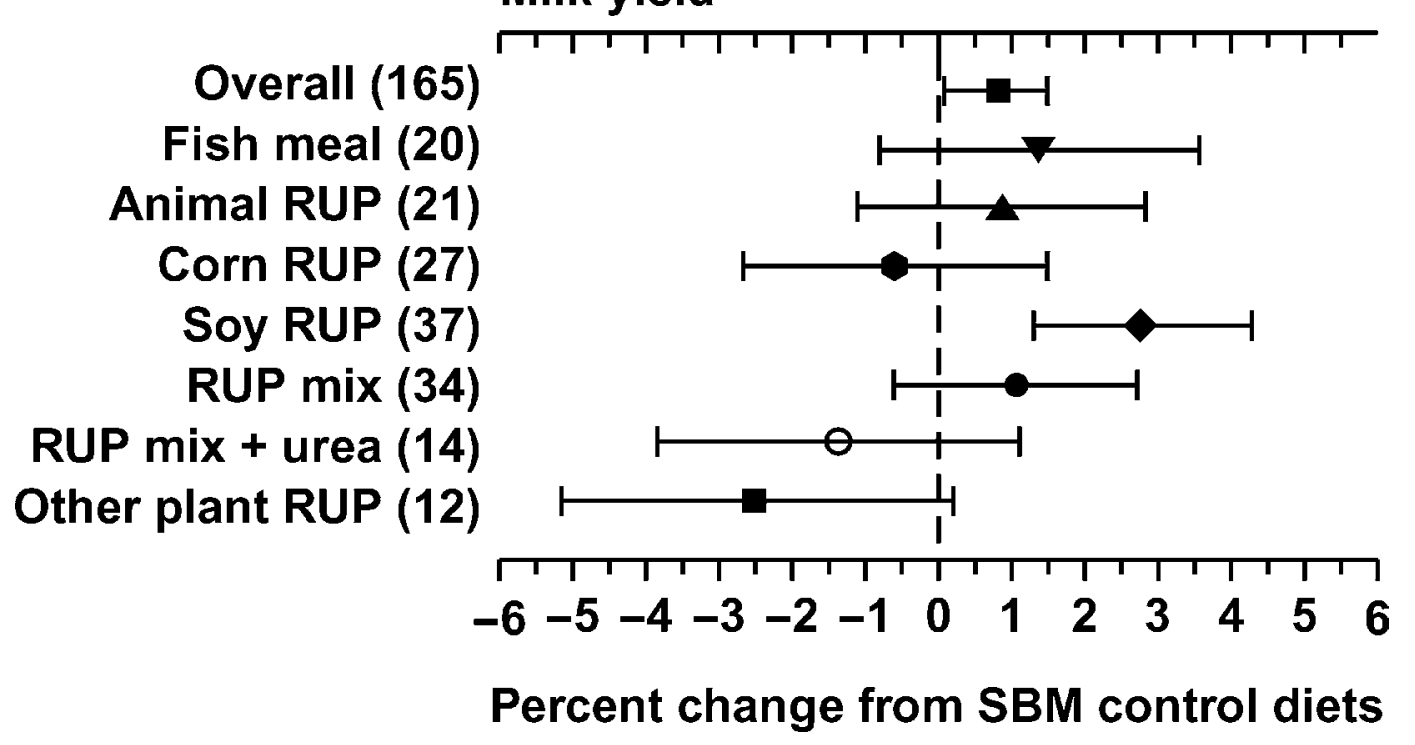

Figure 11. Effect of source of RUP supplement in experimental diets compared with solvent-extracted soybean meal (SBM) control diets on milk production of dairy cows. Means $\pm 95 \%$ confidence intervals $(n)$ are shown.

and/or proportion of AA supplied to the cows. The negative response $(P<0.05)$ in milk $\mathrm{CP}$ percentage to replacing SBM with the RUP mix plus urea $(-3.4 \%)$ and mixtures of plant protein $(-1.3 \%)$ may be related to a numerical decrease in DMI. The poor quality of metabolizable protein supplied by corn by-products deficient in lysine may be the reason for the depressed $(-3.1 \% ; P<0.05)$ milk CP percentage when they were fed to the cows. Because treated soy products increased $(P<0.05)$ milk production, their negative effect $(P<$ 0.05 ) on milk CP percentage may be a dilution effect.

The replacement of SBM with other plant proteins, RUP mix plus urea, corn by-products, and a mixture of animal proteins decreased the mean production of milk $\mathrm{CP}$, but this effect was significant only for RUP mix plus urea and the other plant proteins (Figure 12). The magnitude of the response in milk $\mathrm{CP}$ output to replacement of SBM with treated soy products or the animal, marine, and plant protein mixtures was small. Although not significant, replacing SBM with fish meal increased the yield of milk CP by about $2.5 \%$.

The largest depression in milk fat yield, although not significant, occurred when SBM was replaced with other plant proteins $(-5.2 \%)$, fish meal $(-3.5 \%)$, and RUP mix plus urea $(-3.2 \%)$. The largest increases in milk fat yield (also not significant) occurred when treated soy products $(3.0 \%)$ and mixtures of animal proteins $(1.5 \%)$ replaced SBM in the diet. With the exception of fish meal, these responses suggest that the effect of RUP supplements on milk fat output was largely related to their effects on milk production. The detrimental effect of fish meal on milk fat secretion has been attributed to impairments in ruminal fermentation and/or the postabsorptive metabolism of lipids elicited by polyunsaturated fatty acids in fish oil.

\section{CONCLUSIONS}

Large variation exists in the responses of dairy cows to RUP supplements in research trials. A portion of this variation is explained by the source of $\mathrm{CP}$ in the control diets, the source of RUP fed to the cows, and to a lesser extent the CP percentage of the diet. The quantity and quality of the protein in the control diet and the amount and source of RUP in the experimental diet, therefore, influence the magnitude, either positively or negatively, of the response obtained from RUP supplements in experimental diets in research trials. Compared with SBM, fish meal provided the largest improvement in milk CP yield (2.5\%) but depressed milk fat yield (-3.5\%). Compared with SBM, milk production responses to RUP supplements ranged from $-2.5 \%$ to $+2.75 \%$. Treated soy products provided the largest increase in milk production $(2.75 \%)$ and that in part may be explained by increased DMI. Because of the large variation and small magnitude of response when RUP supplements are fed compared with SBM, efficiency of $\mathrm{N}$ utilization and the cost-to-benefit ratio for these $\mathrm{CP}$ supplements may determine the source and amount of CP to feed to dairy cows in the future. 


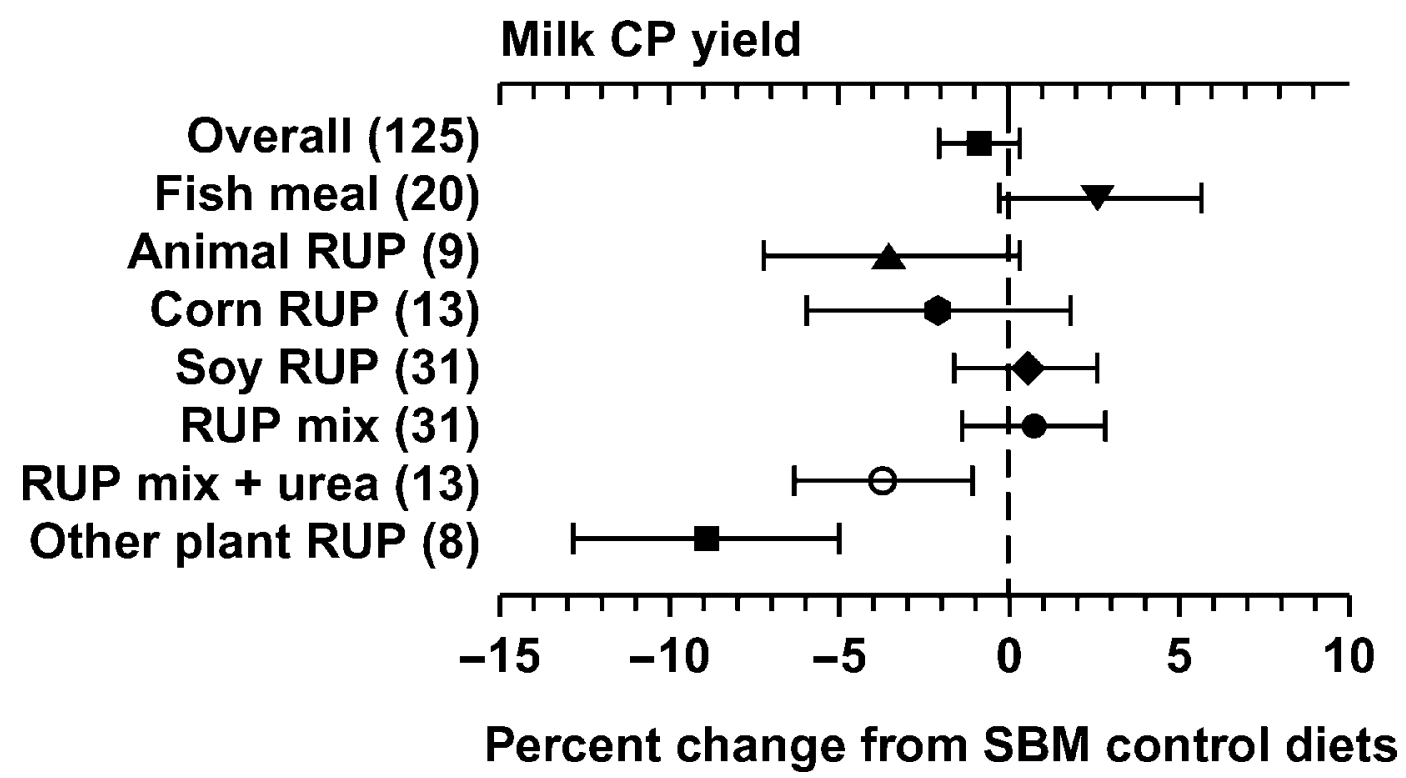

Figure 12. Effect of source of RUP supplement in experimental diets compared with solvent-extracted soybean meal (SBM) control diets on milk CP yield of dairy cows. Means $\pm 95 \%$ confidence intervals $(n)$ are shown.

\section{REFERENCES}

Abu-Ghazaleh, A. A., D. J. Schingoethe, and A. R. Hippen. 2001. Blood amino acids and milk composition from cows fed soybean meal, fish meal, or both. J. Dairy Sci. 84:1174-1181.

Aharoni, Y., A. Arieli, and H. Tagari. 1993. Lactational response of dairy cows to change of degradability of dietary protein and organic matter. J. Dairy Sci. 76:3514-3522.

Ahvenjärvi, S., A. Vanhatalo, and P. Huhtanen. 2002. Supplementing barley or rapeseed meal to dairy cows fed grass-red clover silage: I. Rumen degradability and microbial flow. J. Anim. Sci. 80:2176-2187.

Aldrich, J. M., L. D. Muller, G. A. Varga, and L. C. Griel, Jr. 1993. Nonstructural carbohydrate and protein effects on rumen fermentation, nutrient flow, and performance of dairy cows. J. Dairy Sci. 76:1091-1105.

Allison, R. D., and P. C. Garnsworthy. 2002. Increasing the digestible undegraded protein intake of lactating dairy cows by feeding fish meal or a rumen protected vegetable protein blend. Anim. Feed Sci. Technol. 96:69-81.

Annexstad, R. J., M. D. Stern, D. E. Otterby, J. G. Linn, and W. P. Hansen. 1987. Extruded soybeans and corn gluten meal as supplemental protein sources for lactating dairy cattle. J. Dairy Sci. 70:814-822.

Armentano, L. E., S. J. Bertics, and J. Riesterer. 1993. Lack of response to addition of degradable protein to a low protein diet fed to midlactation dairy cows. J. Dairy Sci. 76:3755-3762.

Armentano, L. E., T. A. Herrington, C. E. Polan, A. J. Moe, J. H. Herbein, and P. Umstadt. 1986. Ruminal degradation of dried brewers grains, wet brewers grains, and soybean meal. J. Dairy Sci. 69:2124-2133.

Atwal, A. S., and J. D. Erfle. 1992. Effects of feeding fish meal to cows on digestibility, milk production, and milk composition. J. Dairy Sci. 75:502-507.

Atwal, A. S., S. Mahadevan, M. S. Wolynetz, and Y. Yu. 1995. Increased milk production of cows in early lactation fed chemically treated soybean meal. J. Dairy Sci. 78:595-603.

Baker, M. J., H. E. Amos, A. Nelson, C. C. Williams, and M. A. Froetschel. 1996. Undegraded intake protein: Effects on milk production and amino acid utilization by cows fed wheat silage. Can. J. Anim. Sci. 76:367-376.
Baker, L. D., J. D. Ferguson, and W. Chalupa. 1995. Responses in urea and true protein of milk to different protein feeding schemes for dairy cows. J. Dairy Sci. 78:2424-2434.

Bargo, F., D. H. Rearte, F. J. Santini, and L. D. Muller. 2001. Ruminal digestion by dairy cows grazing winter oats pasture supplemented with different levels and sources of protein. J. Dairy Sci. 84:2260-2272.

Barney, D. J., D. G. Grieve, G. K. Macleod, and L. G. Young. 1981. Response of cows to dietary crude protein during midlactation. J. Dairy Sci. 64:655-661.

Beauchemin, K. A., W. Z. Yang, and L. M. Rode. 1999. Effects of grain source and enzyme additive on site and extent of nutrient digestion in dairy cows. J. Dairy Sci. 82:378-390.

Benchaar, C., M. Vernay, C. Bayourthe, and R. Moncoulon. 1994. Effects of extrusion of whole horse beans on protein digestion and amino acid absorption in dairy cows. J. Dairy Sci. 77:1360-1371.

Bernard, J. K. 1997. Milk production and composition responses to the source of protein supplements in diets containing wheat middlings. J. Dairy Sci. 80:938-942.

Blauwiekel, R., W. H. Hoover, S. D. Slider, and T. K. Miller. 1990. Effects of fish meal protein supplementation on milk yield and composition and blood constituents of dairy cows. J. Dairy Sci. 73:3217-3221.

Bowman, J. M., D. G. Grieve, J. G. Buchanan-Smith, and G. K. Macleod. 1988. Response of dairy cows in early lactation to sodium hydroxide-treated soybean meal. J. Dairy Sci. 71:982-989.

Broderick, G. A. 1986. Relative value of solvent and expeller soybean meal for lactating dairy cows. J. Dairy Sci. 69:2948-2958.

Broderick, G. A. 1992. Relative value of fish meal versus solvent soybean meal for lactating dairy cows fed alfalfa silage as sole forage. J. Dairy Sci. 75:174-183.

Broderick, G. A. 2003. Effects of varying dietary protein and energy levels on the production of lactating dairy cows. J. Dairy Sci. 86:1370-1381

Broderick, G. A., W. M. Craig, and D. B. Ricker. 1993. Urea versus true protein as supplement for lactating dairy cows fed grain plus mixtures of alfalfa and corn silages. J. Dairy Sci. 76:2266-2274.

Broderick, G. A., D. B. Ricker, and L. S. Driver. 1990. Expeller soybean meal and corn by-products versus solvent soybean meal for lactating dairy cows fed alfalfa silage as sole forage. J. Dairy Sci. 73:453-462. 
Bruckental, I., D. Drori, M. Kaim, H. Lehrer, and Y. Folman. 1989. Effects of source and level of protein on milk yield and reproductive performance of high-producing primiparous and multiparous dairy cows. Anim. Prod. 48:319-329.

Bruckental, I., M. Holtzman, M. Kaim, Y. Aharoni, S. Zamwell, H. Voet, and A. Arieli. 2000. Effect of amount of undegradable crude protein in the diets of high-yielding dairy cows on energy balance and reproduction. Livest. Prod. Sci. 63:131-140.

Calsamiglia, S., G. Caja, M. D. Stern, and B. A. Crooker. 1995. Effects of ruminal versus duodenal dosing of fish meal on ruminal fermentation and milk composition. J. Dairy Sci. 78:1999-2007.

Calsamiglia, S., D. D. Hongerholt, B. A. Crooker, M. D. Stern, G. F. Hartnell, and R. L. Hintz. 1992. Effect of fish meal and expellerprocessed soybean meal fed to dairy cows receiving bovine somatotropin (sometribove). J. Dairy Sci. 75:2454-2462.

Cameron, M. R., T. H. Klusmeyer, G. L. Lynch, J. H. Clark, and D. R. Nelson. 1991. Effects of urea and starch on rumen fermentation, nutrient passage to duodenum, and performance of cows. J. Dairy Sci. 74:1321-1336.

Canfield, R. W., C. J. Sniffen, and W. R. Butler. 1990. Effects of excess degradable protein on postpartum reproduction and energy balance in dairy cattle. J. Dairy Sci. 73:2342-2349.

Casper, D. P., H. A. Maiga, M. J. Brouk, and D. J. Schingoethe. 1999. Synchronization of carbohydrate and protein sources on fermentation and passage rates in dairy cows. J. Dairy Sci. 82:1779-1790.

Casper, D. P., D. J. Schingoethe, and W. A. Eisenbeisz. 1990. Response of early lactation dairy cows fed diets varying in source of nonstructural carbohydrate and crude protein. J. Dairy Sci. 73:1039-1050.

Council for Agricultural Science and Technology. 2002. Animal diet modification to decrease the potential for nitrogen and phosphorus pollution. Issue Paper No 21. Council for Agricultural Science and Technology, Ames, Iowa.

Chan, S. C., J. T. Huber, C. B. Theurer, Z. Wu, K. H. Chen, and J. M. Simas. 1997. Effects of supplemental fat and protein source on ruminal fermentation and nutrient flow to the duodenum in dairy cows. J. Dairy Sci. 80:152-159.

Chen, K. H., J. T. Huber, C. B. Theurer, D. V. Armstrong, R. C. Wanderley, J. M. Simas, S. C. Chan, and J. L. Sullivan. 1993. Effect of protein quality and evaporative cooling on lactational performance of Holstein cows in hot weather. J. Dairy Sci. 76:819-825.

Christensen, R. A., M. R. Cameron, J. H. Clark, J. K. Drackley, J. M. Lynch, and D. M. Barbano. 1994. Effects of amount of protein and ruminally protected amino acids in the diet of dairy cows fed supplemental fat. J. Dairy Sci. 77:1618-1629.

Christensen, R. A., M. R. Cameron, T. H. Klusmeyer, J. P. Elliott, J. H. Clark, D. R. Nelson, and Y. Yu. 1993a. Influence of amount and degradability of dietary protein on nitrogen utilization by dairy cows. J. Dairy Sci. 76:3497-3513.

Christensen, R. A., G. L. Lynch, J. H. Clark, and Y. Yu. 1993b. Influence of amount and degradability of protein on production of milk and milk components by lactating Holstein cows. J. Dairy Sci. 76:3490-3496.

Christensen, R. A., T. R. Overton, J. H. Clark, J. K. Drackley, D. R. Nelson, and S. A. Blum. 1996. Effects of dietary fat with or without nicotinic acid on nutrient flow to the duodenum of dairy cows. J. Dairy Sci. 79:1410-1424.

Clark, J. H., T. H. Klusmeyer, and M. R. Cameron. 1992. Microbial protein synthesis and flows of nitrogen fractions to the duodenum of dairy cows. J. Dairy Sci. 75:2304-2323.

Cody, R. F., J. J. Murphy, and D. J. Morgan. 1990. Effect of supplementary crude protein level and degradability and abomasal nitrogen flow in sheep. Anim. Prod. 51:235-244.

Colin-Schoellen, O., F. Laurent, B. Vignon, J. C. Robert, and B. Sloan. 1995. Interactions of ruminally protected methionine and lysine with protein source or energy level in the diets of cows. J. Dairy Sci. 78:2807-2818.

Cunningham, K. D., M. J. Cecava, and T. R. Johnson. 1993. Nutrient digestion, nitrogen, and amino acid flows in lactating cows fed soybean hulls in place of forage or concentrate. J. Dairy Sci. 76:3523-3535.

Cunningham, K. D., M. J. Cecava, and T. R. Johnson. 1994. Flows of nitrogen and amino acids in dairy cows fed diets containing supplemental feather meal and blood meal. J. Dairy Sci. 77:3666-3675.

Cunningham, K. D., M. J. Cecava, T. R. Johnson, and P. A. Ludden. 1996. Influence of source and amount of dietary protein on milk yield by cows in early lactation. J. Dairy Sci. 79:620-630.

Curtis, P. S., and X. Z. Wang. 1998. A meta-analysis of elevated $\mathrm{CO}_{2}$ effects on woody plant mass, form, and physiology. Oecologia 113:299-313.

Davidson, S., B. A. Hopkins, D. E. Diaz, S. M. Bolt, C. Brownie, V. Fellner, and L. W. Whitlow. 2003. Effects of amounts and degradability of dietary protein on lactation, nitrogen utilization, and excretion in early lactation Holstein cows. J. Dairy Sci. 86:1681-1689.

De Gracia, M., F. G. Owen, and S. R. Lowry. 1989. Corn gluten meal and blood meal mixture for dairy cows in midlactation. J. Dairy Sci. 72:3064-3069.

Dhiman, T. R., A. C. Korevaar, and L. D. Satter. 1997. Particle size of roasted soybeans and the effect on milk production of dairy cows. J. Dairy Sci. 80:1722-1727.

Dhiman, T. R., and L. D. Satter. 1993. Protein as the first-limiting nutrient for lactating dairy cows fed high proportions of good quality alfalfa silage. J. Dairy Sci. 76:1960-1971.

Erasmus, L. J., P. M. Botha, and A. Kistner. 1992. Effect of yeast culture supplement on production, rumen fermentation, and duodenal nitrogen flow in dairy cows. J. Dairy Sci. 75:3056-3065.

Erasmus, L. J., P. M. Botha, and H. H. Meissner. 1994. Effect of protein source on ruminal fermentation and passage of amino acids to the small intestine of lactating cows. J. Dairy Sci. 77:3655-3665.

Feng, P., W. H. Hoover, T. K. Miller, and R. Blauweikel. 1993. Interactions of fiber and nonstructural carbohydrates on lactation and ruminal function. J. Dairy Sci. 76:1324-1333.

Firkins, J. L. 1996. Maximizing microbial protein synthesis in the rumen. J. Nutr. 126:1347S-1354S.

Garcia-Bojalil, C. M., C. R. Staples, C. A. Risco, J. D. Savio, and W. W. Thatcher. 1998. Protein degradability and calcium salts of long-chain fatty acids in the diets of lactating dairy cows: Productive responses. J. Dairy Sci. 81:1374-1384.

Garnsworthy, P. C. 1989. The interaction between dietary fibre level and protein degradability in dairy cows. J. Dairy Sci. 48:271-281.

Garnsworthy, P. C., and G. P. Jones. 1987. The influence of body condition at calving and dietary protein supply on voluntary food intake and performance in dairy cows. Anim. Prod. 44:347-353.

Grant, R. J., and S. G. Haddad. 1998. Effect of a mixture of feather and blood meals on lactational performance of dairy cows. J. Dairy Sci. 81:1358-1363.

Grings, E. E., R. E. Roffler, and D. P. Deitelhoff. 1992. Responses of dairy cows to additions of distillers dried grains with solubles in alfalfa-based diets. J. Dairy Sci. 75:1946-1953.

Grummer, R. R., M. L. Luck, and J. A. Barmore. 1994. Lactational performance of dairy cows fed raw soybeans, with or without animal by-product proteins, or roasted soybeans. J. Dairy Sci. 77:1354-1359.

Grummer, R. R., K. Slark, S. J. Bertics, M. L. Luck, and J. A. Barmore. 1996. Soybeans versus animal sources of rumen-undegradable protein and fat for early lactation dairy cows. J. Dairy Sci. 79:1809-1816.

Hadsell, D. L., and J. L. Sommerfeldt. 1988. Chickpeas as a protein and energy supplement for high producing dairy cows. J. Dairy Sci. 71:762-772.

Harris, B., Jr., D. E. Dorminey, W. A. Smith, H. H. Van Horn, and C. J. Wilcox. 1992. Effects of feather meal at two protein concentrations and yeast culture on production parameters in lactating dairy cows. J. Dairy Sci. 75:3524-3530.

Hedges, L. V., J. Gurevitch, and P. S. Curtis. 1999. The meta-analysis of response ratios in experimental ecology. Ecology 80:1150-1156.

Henderson, S. J., H. E. Amos, and J. J. Evans. 1985. Influence of dietary protein concentration and degradability on milk produc- 
tion, composition, and ruminal protein metabolism. J. Dairy Sci. 68:2227-2237.

Henson, J. E., D. J. Schingoethe, and H. A. Maiga. 1997. Lactational evaluation of protein supplements of varying ruminal degradabilities. J. Dairy Sci. 80:385-392.

Herrera-Saldana, R. E., R. Gomez-Alarcon, M. Torabi, and J. T. Huber. 1990. Influence of synchronizing protein and starch degradation in the rumen on nutrient utilization and microbial synthesis. J. Dairy Sci. 73:142-148.

Herrera-Saldana, R. E., and J. T. Huber. 1989. Influence of varying protein and starch degradabilities on performance of lactating cows. J. Dairy Sci. 72:1477-1483.

Higginbotham, G. E., M. Tobari, and J. T. Huber. 1989. Influence of dietary protein concentration and degradability on performance of lactating cows during hot environmental temperatures. J. Dairy Sci. 72:2554-2564.

Hoffman, P. C., R. R. Grummer, R. D. Shaver, G. A. Broderick, and T. R. Drendel. 1991. Feeding supplemental fat and undegraded intake protein to early lactation dairy cows. J. Dairy Sci. 74:3468-3474.

Hongerholt, D. D., and L. D. Muller. 1998. Supplementation of rumenundegradable protein to the diets of early lactation Holstein cows on grass pasture. J. Dairy Sci. 81:2204-2214.

Hoover, W. H., and S. R. Stokes. 1991. Balancing carbohydrates and proteins for optimum rumen microbial yield. J. Dairy Sci. 74:3630-3644.

Howard, H. J., E. P. Aalseth, G. D. Adams, L. J. Bush, R. W. McNew, and L. J. Dawson. 1987. Influence of dietary protein on reproductive performance of dairy cows. J. Dairy Sci. 70:1563-1571.

Ipharraguerre, I. R., Z. Shabi, J. H. Clark, and D. E. Freeman. 2002. Ruminal fermentation and nutrient digestion by dairy cows fed varying amounts of soyhulls as a replacement for corn grain. J. Dairy Sci. 85:2890-2904.

Jaquette, R. D., A. H. Rakes, and W. J. Croom, Jr. 1987. Effect of amount and source of dietary nitrogen on milk fat depression in early lactation dairy cows. J. Dairy Sci. 70:1202-1210.

Jones, G. P., and P. C. Garnsworthy. 1988. The effects of body condition at calving and dietary protein content on dry-matter intake and performance in lactating dairy cows given diets of low energy content. Anim. Prod. 47:321-333.

Kaim, M., H. Neumark, Y. Folman, and W. Kaufman. 1987. The effect of two concentrations of dietary protein and of formaldehydetreated soya-bean meal on the performance of high-yielding dairy cows. Anim. Prod. 44:333-345.

Kalscheur, K. F., B. B. Teter, L. S. Piperova, and R. A. Erdman. 1997a. Effect of dietary forage concentration and buffer addition on duodenal flow of trans-C18:1 fatty acids and milk fat production in dairy cows. J. Dairy Sci. 80:2104-2114.

Kalscheur, K. F., B. B. Teter, L. S. Piperova, and R. A. Erdman. 1997b. Effect of fat source on duodenal flow of trans-C18:1 fatty acids and milk fat production in dairy cows. J. Dairy Sci. 80:2115-2126.

Kalscheur, K. F., J. H. Vandersall, R. A. Erdman, R. A. Kohn, and E. Russek-Cohen. 1999. Effects of dietary crude protein concentration and degradability on milk production responses of early, mid, and late lactation dairy cows. J. Dairy Sci. 82:545-554.

Keery, C. M., and H. E. Amos. 1993. Effects of source and level of undegraded intake protein on nutrient use and performance of early lactation cows. J. Dairy Sci. 76:499-513.

Khorasani, G. R., G. De Boer, and J. J. Kennelly. 1996. Response of early lactation cows to ruminally undegradable protein in the diet. J. Dairy Sci. 79:446-453.

Kim, Y. K., D. J. Schingoethe, D. P. Casper, and F. C. Ludens. 1991. Lactational response of dairy cows to increased dietary crude protein with added fat. J. Dairy Sci. 74:3891-3899.

King, K. J., J. T. Huber, M. Sadik, W. G. Bergen, A. L. Grant, and V. L. King. 1990. Influence of dietary protein sources on the amino acid profiles available for digestion and metabolism in lactating cows. J. Dairy Sci. 73:3208-3216.

Klusmeyer, T. H., G. L. Lynch, J. H. Clark, and D. R. Nelson. 1991a. Effects of calcium salts of fatty acids and proportion of forage in diet on ruminal fermentation and nutrient flow to duodenum of cows. J. Dairy Sci. 74:2220-2232.

Klusmeyer, T. H., G. L. Lynch, J. H. Clark, and D. R. Nelson. 1991b. Effects of calcium salts of fatty acids and protein source on ruminal fermentation and nutrient flow to duodenum of cows. J. Dairy Sci. 74:2206-2219.

Klusmeyer, T. H., R. D. McCarthy, Jr., J. H. Clark, and D. R. Nelson. 1990. Effects of source and amount of protein on ruminal fermentation and passage of nutrients to the small intestine of lactating cows. J. Dairy Sci. 73:3526-3537.

Knapp, D. M., R. R. Grummer, and M. R. Dentine. 1991. The response of lactating dairy cows to increasing levels of whole roasted soybeans. J. Dairy Sci. 74:2563-2572.

Knowlton, K. F., B. P. Glenn, and R. A. Erdman. 1998. Performance, ruminal fermentation, and site of starch digestion in early lactation cows fed corn grain harvested and processed differently. J. Dairy Sci. 81:1972-1984.

Komaragiri, M. V., and R. A. Erdman. 1997. Factors affecting body tissue mobilization in early lactation dairy cows. 1. Effect of dietary protein on mobilization of body fat and protein. J. Dairy Sci. 80:929-937.

Kung, L., Jr., J. T. Huber, and L. D. Satter. 1983. Influence of nonprotein nitrogen and protein of low rumen degradability on nitrogen flow and utilization in lactating dairy cows. J. Dairy Sci. 66:1863-1872.

Lees, J. A., J. D. Oldham, W. Haresign, and P. C. Garnsworthy. 1990. The effect of patterns of rumen fermentation on the response by dairy cows to dietary protein concentration. Br. J. Nutr. 63:177-186.

Léonard, M., and E. Block. 1988. Effect of ration protein content and solubility on milk production of primiparous Holstein heifers. J. Dairy Sci. 71:2709-2722.

Leonardi, C., M. Stevenson, and L. E. Armentano. 2003. Effect of two levels of crude protein and methionine supplementation on performance of dairy cows. J. Dairy Sci. 86:4033-4042.

Lines, L. W., and W. P. Weiss. 1996. Use of nitrogen from ammoniated alfalfa hay, urea, soybean meal, and animal protein meal by lactating cows. J. Dairy Sci. 79:1992-1999.

Lu, C. D., N. A. Jorgensen, and L. D. Satter. 1988. Site and extent of nutrient digestion in lactating dairy cows fed alfalfa protein concentrate or soybean meal. J. Dairy Sci. 71:697-704.

Lundquist, R. G., D. E. Otterby, and J. G. Linn. 1986. Influence of formaldehyde-treated soybean meal on milk production. J. Dairy Sci. 69:1337-1345.

Lynch, G. L., T. H. Klusmeyer, M. R. Cameron, J. H. Clark, and D. R. Nelson. 1991. Effects of somatotropin and duodenal infusion of amino acids on nutrient passage to duodenum and performance of dairy cows. J. Dairy Sci. 74:3117-3127.

Mabjeesh, S. J., J. Galindez, O. Kroll, and A. Arieli. 2000. The effect of roasting nonlinted whole cottonseed on milk production by dairy cows. J. Dairy Sci. 83:2557-2563.

Maiga, H. A., and D. J. Schingoethe. 1997. Optimizing the utilization of animal fat and ruminal bypass proteins in the diets of lactating dairy cows. J. Dairy Sci. 80:343-352.

Mansfield, H. R., and M. D. Stern. 1994. Effects of soybean hulls and lignosulfonate-treated soybean meal on ruminal fermentation in lactating dairy cows. J. Dairy Sci. 77:1070-1083.

Mansfield, H. R., M. D. Stern, and D. E. Otterby. 1994. Effects of beet pulp and animal by-products on milk yield and in vitro fermentation by rumen microorganisms. J. Dairy Sci. 77:205-216.

Manson, F. J., and J. D. Leaver. 1988. The influence of dietary protein intake and hoof trimming on lameness in dairy cattle. Anim. Prod. 47:191-199.

Mäntysaari, P. E., C. J. Sniffen, T. V. Muscato, J. M. Lynch, and D. M. Barbano. 1989. Performance of cows in early lactation fed isonitrogenous diets containing soybean meal or animal by-product meals. J. Dairy Sci. 72:2958-2967.

McCarthy, R. D., Jr., T. H. Klusmeyer, J. L. Vicini, J. H. Clark, and D. R. Nelson. 1989. Effects of source of protein and carbohydrate on ruminal fermentation and passage of nutrients to the small intestine of lactating cows. J. Dairy Sci. 72:2002-2016. 
McCormick, M. E., D. D. French, T. F. Brown, G. J. Cuomo, A. M. Chapa, J. M. Fernandez, J. F. Beatty, and D. C. Blouin. 1999. Crude protein and rumen undegradable protein effects on reproduction and lactation performance of Holstein cows. J. Dairy Sci. 82:2697-2708.

McCormick, M. E., D. D. Redfearn, J. D. Ward, and D. C. Blouin. 2001. Effect of protein source and soluble carbohydrate addition on rumen fermentation and lactation performance of Holstein cows. J. Dairy Sci. 84:1686-1697.

McGuffey, R. K., H. B. Green, and R. P. Basson. 1990. Lactation response of dairy cows receiving bovine somatotropin and fed rations varying in crude protein and undegradable intake protein. J. Dairy Sci. 73:2437-2443.

Mielke, C. D., and D. J. Schingoethe. 1981. Heat-treated soybeans for lactating cows. J. Dairy Sci. 64:1579-1585.

Nakamura, T., T. J. Klopfenstein, F. G. Owen, R. A. Britton, R. J. Grant, and T. S. Winowiski. 1992. Nonenzymatically browned soybean meal for lactating dairy cows. J. Dairy Sci. 75:3519-3523.

NRC. 2001. Nutrient Requirements of Dairy Cattle. 7th rev. ed. Natl. Acad. Sci., Washington, DC.

Nichols, J. R., D. J. Schingoethe, H. A. Maiga, M. J. Brouk, and M. S. Piepenbrink. 1998. Evaluation of corn distillers grains and ruminally protected lysine and methionine for lactating dairy cows. J. Dairy Sci. 81:482-491.

Noftsger, S., and N. R. St-Pierre. 2003. Supplementation of methionine and selection of highly digestible rumen undegradable protein to improve nitrogen efficiency for milk production. J. Dairy Sci. 86:958-969.

Oba, M., and M. S. Allen. 2003. Effects of diet fermentability on efficiency of microbial nitrogen production in lactating dairy cows. J. Dairy Sci. 86:195-207.

Ohajuruka, O. A., Z. G. Wu, and D. L. Palmquist. 1991. Ruminal metabolism, fiber, and protein digestion by lactating cows fed calcium soap or animal-vegetable fat. J. Dairy Sci. 74:2601-2609.

Oldick, B. S., J. L. Firkins, and N. R. St-Pierre. 1999. Estimation of microbial nitrogen flow to the duodenum of cattle based on dry matter intake and diet composition. J. Dairy Sci. 82:1497-1511.

Oliveira, J. S., J. T. Huber, J. M. Simas, C. B. Theurer, and R. S. Swingle. 1995. Effect of sorghum grain processing on site and extent of digestion of starch in lactating dairy cows. J. Dairy Sci. 78:1318-1327.

O'Mara, F. P., J. J. Murphy, and M. Rath. 1998. Effect of amount of dietary supplement and source of protein on milk production, ruminal fermentation, and nutrient flows in dairy cows. J. Dairy Sci. 81:2430-2439.

Overton, T. R., M. R. Cameron, J. P. Elliott, J. H. Clark, and D. R. Nelson. 1995. Ruminal fermentation and passage of nutrients to the duodenum of lactating cows fed mixtures of corn and barley. J. Dairy Sci. 78:1981-1998.

Overton, T. R., L. S. Emmert, and J. H. Clark. 1998. Effects of source of carbohydrate and protein and rumen-protected methionine on performance of cows. J. Dairy Sci. 81:221-228.

Owen, F. G., and L. L. Larson. 1991. Corn distillers dried grains versus soybean meal in lactation diets. J. Dairy Sci. 74:972-979.

Palmquist, D. L., and W. P. Weiss. 1994. Blood and hydrolyzed feather meals as sources of undegradable protein in high fat diets for cows in early lactation. J. Dairy Sci. 77:1630-1643.

Pantoja, J., J. L. Firkins, and M. L. Eastridge. 1995. Site of digestion and milk production by cows fed fats differing in saturation, esterification, and chain length. J. Dairy Sci. 78:2247-2258.

Pantoja, J., J. L. Firkins, M. L. Eastridge, and B. L. Hull. 1994. Effects of fat saturation and source of fiber on site of nutrient digestion and milk production by lactating dairy cows. J. Dairy Sci. 77:2341-2356.

Petit, H. V., and D. M. Veira. 1991. Effects of grain level and protein source on yield, feed intake, and blood traits of lactating cows fed alfalfa silage. J. Dairy Sci. 74:1923-1932.

Pires, A. V., M. L. Eastridge, and J. L. Firkins. 1996. Roasted soybeans, blood meal, and tallow as sources of fat and ruminally undegradable protein in the diets of lactating cows. J. Dairy Sci. 79:1603-1610.
Pires, A. V., M. L. Eastridge, J. L. Firkins, and Y. C. Lin. 1997. Effects of heat treatment and physical processing of cottonseed on nutrient digestibility and production performance by lactating cows. J. Dairy Sci. 80:1685-1694.

Polan, C. E., G. Cozzi, P. Berzaghi, and I. Andrighetto. 1997. A blend of animal and cereal protein or fish meal as partial replacement for soybean meal in the diets of lactating Holstein cows. J. Dairy Sci. 80:160-166.

Polan, C. E., T. A. Herrington, W. A. Wark, and L. E. Armentano. 1985. Milk production response to diets supplemented with dried brewers grains, wet brewers grains, or soybean meal. J. Dairy Sci. 68:2016-2026.

Poore, M. H., J. A. Moore, T. P. Eck, R. S. Swingle, and C. B. Theurer. 1993. Effect of fiber source and ruminal starch degradability on site and extent of digestion in dairy cows. J. Dairy Sci. 76:2244-2253.

Powers, W. J., H. H. Van Horn, B. Harris, Jr., and C. J. Wilcox. 1995. Effects of variable sources of distillers dried grains plus solubles on milk yield and composition. J. Dairy Sci. 78:388-396.

Prange, R. W., M. D. Stern, N. A. Jorgensen, and L. D. Satter. 1984. Site and extent of digestion in lactating cows fed alfalfa silage or baled alfalfa hay. J. Dairy Sci. 67:2308-2314.

Price, S. G., L. D. Satter, and N. A. Jorgensen. 1988. Dehydrated alfalfa in dairy cow diets. J. Dairy Sci. 71:727-736.

Putnam, D. E., C. G. Schwab, M. T. Socha, N. L. Whitehouse, N. A. Kierstead, and B. D. Garthwaite. 1997. Effect of yeast culture in the diets of early lactation dairy cows on ruminal fermentation and passage of nitrogen fractions and amino acids to the small intestine. J. Dairy Sci. 80:374-384.

Reynal, S. M., and G. A. Broderick. 2003. Effects of feeding dairy cows protein supplements of varying ruminal degradability. J. Dairy Sci. 86:835-843.

Reynal, S. M., G. A. Broderick, S. Ahvenjarvi, and P. Huhtanen. 2003. Effect of feeding protein supplements of differing degradability on omasal flow of microbial and undegraded protein. J. Dairy Sci. 86:1292-1305.

Robinson, P. H., and J. J. Kennelly. 1988. Influence of intake of rumen undegradable protein on milk production of late lactation Holstein cows. J. Dairy Sci. 71:2135-2142.

Robinson, P. H., and R. E. McQueen. 1994. Influence of supplemental protein source and feeding frequency on rumen fermentation and performance in dairy cows. J. Dairy Sci. 77:1340-1353.

Robinson, P. H., R. E. McQueen, and P. L. Burgess. 1991. Influence of rumen undegradable protein levels on feed intake and milk production of dairy cows. J. Dairy Sci. 74:1623-1631.

Robinson, P. H., and C. J. Sniffen. 1984. Forestomach and whole tract digestibility for lactating dairy cows as influenced by feeding frequency. J. Dairy Sci. 68:857-867.

Robinson, P. H., C. J. Sniffen, and P. J. Van Soest. 1985. Influence of level of feed intake on digestion and bacterial yield in the forestomachs of dairy cattle. Can. J. Anim. Sci. 65:437-444.

Rode, L. M., D. C. Weakley, and L. D. Satter. 1985. Effect of forage amount and particle size in diets of lactating dairy cows on site of digestion and microbial protein synthesis. Can. J. Anim. Sci. 65:101-111.

Rodriguez, L. A., C. C. Stallings, J. H. Herbein, and M. L. McGilliard. 1997. Effect of degradability of dietary protein and fat on ruminal, blood, and milk components of Jersey and Holstein cows. J. Dairy Sci. 80:353-363.

Roseler, D. K., J. D. Ferguson, C. J. Sniffen, and J. Herrema. 1993. Dietary protein degradability effects on plasma and milk urea nitrogen and milk nonprotein nitrogen in Holstein cows. J. Dairy Sci. 76:525-534.

Santos, F. A. P., J. T. Huber, C. B. Theurer, R. S. Swingle, J. M. Simas, K. H. Chen, and P. Yu. 1998a. Milk yield and composition of lactating cows fed steam-flaked sorghum and graded concentrations of ruminally degradable protein. J. Dairy Sci. 81:215-220.

Santos, F. A. P., F. E. P. Santos, C. B. Theurer, and J. T. Huber. 1998b. Effects of rumen-undegradable protein on dairy cow performance: A 12-year literature review. J. Dairy Sci. 81:3182-3213.

Santos, K. A., M. D. Stern, and L. D. Satter. 1984. Protein degradation in the rumen and amino acid absorption in the small intestine 
of lactating dairy cattle fed various protein sources. J. Anim. Sci. $58: 244-255$.

Schingoethe, D. J., D. P. Casper, C. Yang, D. J. Illg, J. L. Sommerfeldt, and C. R. Mueller. 1988. Lactational response to soybean meal, heated soybean meal, and extruded soybeans with ruminally protected methionine. J. Dairy Sci. 71:173-180.

Sloan, B. K., and P. Rowlinson. 1988. The influence of a formulated excess of rumen degradable protein or undegradable protein on milk production in dairy cows in early lactation. Anim. Prod. 46:13-22.

Small, J. C., and F. J. Gordon. 1990. A comparison of the responses by lactating cows given grass silage to changes in the degradability or quantity of protein offered in the supplement. Anim. Prod. 50:391-398.

Son, J., R. J. Grant, and L. L. Larson. 1996. Effects of tallow and escape protein on lactational and reproductive performance of dairy cows. J. Dairy Sci. 79:822-830.

Spain, J. N., C. E. Polan, and B. A. Watkins. 1995. Evaluating effects of fish meal on milk fat yield of dairy cows. J. Dairy Sci. 78:1142-1153.

Stern, M. D., L. M. Rode, R. W. Prange, R. H. Stauffacher, and L. D. Satter. 1983. Ruminal protein degradation of corn gluten meal in lactating dairy cattle fitted with duodenal T-type cannulae. J. Anim. Sci. 56:194-205.

Stern, M. D., K. A. Santos, and L. D. Satter. 1985. Protein degradation in rumen and amino acid absorption in small intestine of lactating dairy cattle fed heat-treated whole soybeans. J. Dairy Sci. 68:45-56.

Stokes, S. R., W. H. Hoover, T. K. Miller, and R. Blauweikel. 1991. Ruminal digestion and microbial utilization of diets varying in type of carbohydrates and protein. J. Dairy Sci. 74:871-881.

St-Pierre, N. R. 2001. Integrating quantitative findings from multiple studies using mixed model methodology. J. Dairy Sci. 84:741-755.

Tice, E. M., M. L. Eastridge, and J. L. Firkins. 1993. Raw soybeans and roasted soybeans of different particle sizes. 1. Digestibility and utilization by lactating cows. J. Dairy Sci. 76:224-235.

Titgemeyer, E. C., and J. E. Shirley. 1997. Effect of processed grain sorghum and expeller soybean meal on performance of lactating cows. J. Dairy Sci. 80:714-721.

Tomlinson, A. P., H. H. Van Horn, C. J. Wilcox, and B. Harris, Jr. 1994. Effects of undegradable protein and supplemental fat on milk yield and composition and physiological responses of cows. J. Dairy Sci. 77:145-156.

van Dijk, H. J., G. D. O’Dell, P. R. Perry, and L. W. Grimes. 1983. Extruded versus raw ground soybeans for dairy cows in early lactation. J. Dairy Sci. 66:2521-2525.

Van Horn, H. H., O. Blanco, B. Harris, Jr., and D. K. Beede. 1985. Interaction of protein percent with caloric density and protein source for lactating dairy cows. J. Dairy Sci. 68:1682-1695.

Voelker, J. A., and M. S. Allen. 2003. Pelleted beet pulp substituted for high-moisture corn: 3. Effects on ruminal fermentation, $\mathrm{pH}$, and microbial protein efficiency in lactating dairy cows. J. Dairy Sci. 86:3562-3570.
Voss, V. L., D. Stehr, L. D. Satter, and G. A. Broderick. 1988. Feeding lactating dairy cows proteins resistant to ruminal degradation. J. Dairy Sci. 71:2428-2439.

Waltz, D. M., M. D. Stern, and D. J. Illg. 1989. Effect of ruminal protein degradation of blood meal and feather meal on the intestinal amino acid supply. J. Dairy Sci. 72:1509-1518.

Wattiaux, M. A., D. K. Combs, and R. D. Shaver. 1994. Lactational responses to ruminally undegradable protein by dairy cows fed diets based on alfalfa silage. J. Dairy Sci. 77:1604-1617.

Weigel, D. J., J. P. Elliott, and J. H. Clark. 1997. Effects of amount and ruminal degradability of protein on nutrient digestibility and production by cows fed tallow. J. Dairy Sci. 80:1150-1159.

Wheeler, J. G., H. E. Amos, M. A. Froetschel, J. C. Coomer, T. Maddox, and J. M. Fernandez. 1995. Responses of early lactation cows fed winter and summer annual forages and undegradable intake protein. J. Dairy Sci. 78:2767-2781.

Windschitl, P. M. 1991. Lactational performance of high producing dairy cows fed diets containing salmon meal and urea. J. Dairy Sci. 74:3475-3485.

Winsryg, M. D., M. J. Arambel, and J. L. Walters. 1991. The effect of protein degradability on milk composition and production of early lactation, somatotropin-injected cows. J. Dairy Sci. 74:1648-1653.

Wohlt, J. E., S. L. Chmiel, P. K. Zajac, L. Backer, D. B. Blethen, and J. L. Evans. 1991. Dry matter intake, milk yield and composition, and nitrogen use in Holstein cows fed soybean, fish, or corn gluten meals. J. Dairy Sci. 74:1609-1622.

Wu, Z., and L. D. Satter. 2000. Milk production during the complete lactation of dairy cows fed diets containing different amounts of protein. J. Dairy Sci. 83:1042-1051.

Yang, W. Z., K. A. Beauchemin, K. M. Koenig, and L. M. Rode. 1997. Comparison of hull-less barley, barley, or corn for lactating cows: Effects on extent of digestion and milk production. J. Dairy Sci. $80: 2475-2486$.

Yoon, I. K., and M. D. Stern. 1996. Effects of Saccharomyces cerevisiae and Aspergillus oryzae cultures on ruminal fermentation in dairy cows. J. Dairy Sci. 79:411-417.

Younker, R. S., S. D. Winland, J. L. Firkins, and B. L. Hull. 1998. Effects of replacing forage fiber or nonfiber carbohydrates with dried brewers grains. J. Dairy Sci. 81:2645-2656.

Zhu, J. S., S. R. Stokes, and M. R. Murphy. 1997. Substitution of neutral detergent fiber from forage with neutral detergent fiber from by-products in the diets of lactating cows. J. Dairy Sci. 80:2901-2906.

Zimmerman, C. A., A. H. Rakes, T. E. Daniel, and B. A. Hopkins. 1992. Effect of total and rumen undegradable protein on the performance of cows fed low fiber diets. J. Dairy Sci. 75:19541964.

Zimmerman, C. A., A. H. Rakes, R. D. Jaquette, B. A. Hopkins, and W. J. Croom, Jr. 1991. Effects of protein level and forage source on milk production and composition in early lactation dairy cows. J. Dairy Sci. 74:980-990. 